\title{
Influence of Pre-Existing Nuclei on the Crystallization Kinetics of Primitive Alkaline Magmas: Insights on the Deep Feeding System of the Campi Flegrei Volcanic District
}

\author{
Barbara Bonechi \\ Dipartimento di Scienze della Terra, Sapienza Università di Roma, P.le Aldo Moro 5, 00185 Rome, Italy; \\ barbara.bonechi@uniroma1.it
}

Received: 4 February 2020; Accepted: 2 March 2020; Published: 4 March 2020

\begin{abstract}
Aiming to evaluate the influence of pre-existing nuclei on the clinopyroxene crystallization kinetics, time-series experiments were performed using both natural and vitrified starting materials. Experiments were carried out at pressure of $0.8 \mathrm{GPa}$, temperatures between 1220 and $1250{ }^{\circ} \mathrm{C}$, and dwell times ranging from 0.16 to $12 \mathrm{~h}$. Clinopyroxene growth rates of the runs performed using the natural starting material containing pre-existing nuclei $\left(\sim 2 \times 10^{-7}\right.$ to $\left.\sim 6 \times 10^{-8} \mathrm{~cm} \cdot \mathrm{s}^{-1}\right)$ are higher than those of the runs performed using the vitrified one $\left(\sim 3 \times 10^{-7}\right.$ to $\left.\sim 2 \times 10^{-8} \mathrm{~cm} \cdot \mathrm{s}^{-1}\right)$. In both cases the growth rates decrease with increasing time. Conversely, clinopyroxene nucleation rates are lower in the experiments performed using the natural powder $\left(10^{2}\right.$ and $\left.10 \mathrm{~mm}^{-3} \cdot \mathrm{s}^{-1}\right)$ compared to those performed with the glassy starting material $\left(10^{5}\right.$ and $\left.10^{3} \mathrm{~mm}^{-3} \cdot \mathrm{s}^{-1}\right)$. The nucleation rates tend to decrease increasing dwell time in all the series up to $\sim 3 \mathrm{~h}$, after which it remains nearly constant. Finally, the combination of the obtained clinopyroxene growth rates with the crystal size analysis of natural clinopyroxenes, allowed to estimate the magma ascent rate and the recharge rate of the Campi Flegrei Volcanic District deep reservoir.
\end{abstract}

Keywords: pre-existing nuclei; heterogeneous nucleation; crystal growth rate; clinopyroxene; high pressure; Procida island

\section{Introduction}

Knowledge of crystallization kinetics in silicate melts is a fundamental tool in the Earth and material sciences due to the importance of crystallization processes in both natural and synthetic melts $[1,2]$. Crystallization consists of two main processes, nucleation and growth, that are both strongly influenced by composition, temperature, volatile components [3-6] and thermal history (e.g., [7-11]). Concerning the nucleation kinetic, it includes two basic mechanisms: homogeneous nucleation during which spontaneous new crystals form in the liquid and heterogeneous nucleation during which, instead, new crystals form on pre-existing surfaces [12]. This latter has long been recognized as an important and more efficient means of nucleation of crystals and bubbles under magmatic conditions (e.g., [3,8,13-15]). Due to this, it is critical for magma crystallization experiments the choice to use as starting material powder of raw or vitrified natural samples or synthetically reconstructed compositions. Glassy starting materials (synthetic composition prepared from oxide and carbonate reagents or vitrified natural samples) have the advantage of being completely homogeneous and able to achieve a state of total chemical equilibrium [16,17]; however, the preparation of these glasses requires multiple fusion cycles at high temperature that strongly affect the nucleation behavior of aluminosilicate melts (e.g., [2,17-19]). This is reflected in the experimental products that could be difficult to correlate to crystallization path of natural magmas. Furthermore, the nucleation behavior 
and, consequently, the textures observed in some experimental products performed using glassy starting material, result to be also influenced by the thermal path before crystallization [20,21]. Indeed, as shown by Masotta et al. [20], in isothermal experiments the crystallization starts before resting temperature $\left(T_{\text {rest }}\right)$ is reached $\left(T<T_{\text {rest }}\right)$. If the crystallized mineral (cpx in this case) remains within its stability field, the further heating up to the $T_{\text {rest }}$ does not allow the dissolution of these early crystals (pre-existing nuclei) favoring a texture formed by many crystals with small sizes ( 10 $\mu \mathrm{m})$. During undercooling experiments, instead, the sample is initially heated at superliquidus conditions (generally 15-30 min of pre-annealing time) before cooling it to the resting temperature. In this condition the crystallization starts at $T>T_{\text {rest }}$ favoring the formation of few crystals with big sizes $(>100 \mu \mathrm{m})$. Conversely, natural crushed starting materials are more easily comparable to natural magmas in terms of crystallization kinetics $[16,17,21]$; however, they are able to reach only a state of partial equilibrium since they are not completely homogenous due to the possible presence of phenocryst cores that may be in disequilibrium with the groundmass. Considering that both natural and vitrified starting materials have advantages and disadvantages, several authors (e.g., [17,22-24]) preferred to use natural starting materials because, due to the virtual presence of nuclei also in aphyric lavas, they yield initial conditions more akin to those of natural magmas.

As observed in the literature (e.g., [8,15,20,25-27]), the occurrence of pre-existing nuclei strongly affects the crystallization kinetics (i.e., nucleation and growth). In the presence of pre-existing nuclei, indeed, the low interfacial energy between them and the nucleating phase concentrates the supply of chemical elements in the liquid near the new growing crystals, limiting in this way the formation of new nucleation sites and favoring, instead, the growth. Many of the works in the literature deal with the influence of pre-existing nuclei on the crystallization kinetics (e.g., [17,25-28]), but they are mainly focused on feldspar crystals. Clinopyroxene is a common mineral in basaltic systems and, due to its wide crystallization range, it may fully record the evolutionary history of a magma. Therefore, in order to evaluate the influence of pre-existing nuclei on the clinopyroxene crystallization kinetics at high pressure, here are reported the results of an experimental investigation performed using both natural and vitrified starting material, which is an alkaline basalt (APR16 sample) [29-32] representative of the least-evolved rocks of the Campi Flegrei Volcanic District (CFVD). The experimental runs were grouped in two series carried out at the same pressure (0.8 GPa): (i) natural starting material series that includes the runs performed in this study at $1225^{\circ} \mathrm{C}$ and at dwell times between 0.16 and $12 \mathrm{~h}$; (ii) glassy starting material series that includes the runs performed by Bonechi et al. [31] at 1250 and $1220^{\circ} \mathrm{C}$ and at dwell times between 0.25 and $9 \mathrm{~h}$, using as starting material the vitrified APR16 powder. Among the experiments of Bonechi et al. [31], the APR16-C1A and APR16-C2A series were chosen to be compared with that performed in this study due to their similar temperatures and effective undercoolings. Moreover, using the clinopyroxene experimental growth rates obtained from natural and synthetic starting materials and the crystal size distribution analysis of clinopyroxenes occurring in the most primitive scoria clasts of the CFVD, an estimate of the deep magma ascent rate and of the recharge rate of the CFVD deep reservoir was made.

\section{Materials and Methods}

\subsection{Starting Material}

The starting material used in this study is a natural rock powder with alkali basaltic composition [29-32] (Table 1). In particular, the natural sample is a primitive K-basalt (APR16 sample) found as scoria clast in the deposits of the Solchiaro eruption ( 22 ka; [33]) located in Procida island, (Campi Flegrei, Italy). The sample consists of $12 \mathrm{vol}$ \% of forsteritic olivine and diopsidic clinopyroxene phenocrysts dispersed in a groundmass made of olivine, clinopyroxene, plagioclase, Ti-magnetite, alkali feldspar and glass $[34,35]$. The powder, used as starting material in the runs of natural starting material series, was obtained by grinding the APR16 rock sample in an agate mortar under acetone. The glass, instead, was prepared by Bonechi et al. [31] by melting for 15 min the APR16 natural powder in a 1-atm 
gas-mixing furnace (Bayerisches Geoinstitut, Bayreuth, Germany) at $1400{ }^{\circ} \mathrm{C}$ and oxygen fugacity buffered at the Nickel-Nickel Oxide level using a $\mathrm{CO} / \mathrm{CO}_{2}$ gas mixture.

Table 1. Composition (wt. \%) of APR16 rock sample and APR16GL starting material.

\begin{tabular}{|c|c|c|}
\hline Sample & APR16 & APR16GL \\
\hline $\mathrm{SiO}_{2}$ & 48.89 & 49.30 \\
\hline $\mathrm{TiO}_{2}$ & 1.23 & 1.33 \\
\hline $\mathrm{Al}_{2} \mathrm{O}_{3}$ & 15.65 & 15.31 \\
\hline $\mathrm{FeO}_{\text {tot }}$ & 8.08 & 7.79 \\
\hline $\mathrm{MnO}$ & 0.14 & 0.14 \\
\hline $\mathrm{MgO}$ & 8.89 & 9.31 \\
\hline $\mathrm{CaO}$ & 11.64 & 12.02 \\
\hline $\mathrm{Na}_{2} \mathrm{O}$ & 2.88 & 2.86 \\
\hline $\mathrm{K}_{2} \mathrm{O}$ & 1.52 & 1.60 \\
\hline $\mathrm{P}_{2} \mathrm{O}_{5}$ & 0.31 & 0.33 \\
\hline Sum & 99.99 & 99.23 \\
\hline L.O.I. & 0.61 & nd \\
\hline $\mathrm{Mg} \#^{1}$ & 0.66 & 0.68 \\
\hline
\end{tabular}

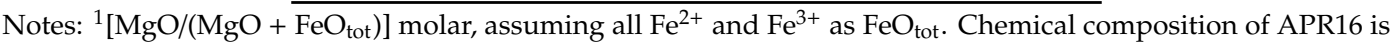
from D'Antonio et al. [34]; APR16GL composition is from Perinelli et al. [32]; nd: not determined.

\subsection{Experimental Procedure}

Experiments were carried out at pressure of $0.8 \mathrm{GPa}$, as function of temperature and time by using the $\frac{1}{2}$ inch end loaded piston cylinder apparatus at the HP-HT Laboratory of the Earth Sciences Department (Sapienza University, Rome, Italy). The assembly consists of an outer $\mathrm{CaF}_{2}$ cell, graphite furnace and $\mathrm{MgO}$ crushable spacers. About $40-50 \mathrm{mg}$ of powdered starting material was dried at $110^{\circ} \mathrm{C}$ for at least $2 \mathrm{~h}$ to remove the moisture before being loaded and pressed into $\mathrm{Au}_{75} \mathrm{Pd}_{25}$ capsules and then welded. For each experiment, the capsule was put in the $\mathrm{MgO}$ crushable spacers and surrounded by powder of alumina. Temperature was measured using a type $\mathrm{D} \mathrm{W}_{3} \mathrm{Re}_{97}-\mathrm{W}_{25} \mathrm{Re}_{75}$ thermocouple and maintained with an uncertainty of $\pm 5^{\circ} \mathrm{C}$. The experimental assembly was first pressurized to the target pressure by a piston-out procedure $[36,37]$ that applies an overpressure of $\sim 10 \%$ of the run pressure and temperature was gradually increased to the resting temperature, while correcting for pressure drops due to stress relaxation within the assembly during heating. The heating rate was set at $150^{\circ} \mathrm{C} / \mathrm{min}$. The sample was maintained at the pressure and temperature for a given duration (nominal duration), and then quenched by turning off the power. The temperature dropped to below $500{ }^{\circ} \mathrm{C}$ within $<5 \mathrm{~s}$ with an average cooling rate of $150^{\circ} \mathrm{C} / \mathrm{s}$. All the runs were self-buffered; when possible $f \mathrm{O}_{2}$ was estimated through the equation of Kress and Carmichael [38] using the liquid $\mathrm{Fe}^{3+} / \mathrm{Fe}_{\text {tot }}$ mole ratios from $K_{\mathrm{D}} \mathrm{Fe}-\mathrm{Mg}$ ol/liq calculated following Toplis [39]. This procedure yielded $f \mathrm{O}_{2}$ values of $\Delta \mathrm{NNO}+0.12$ to +2 , in agreement with those estimated for similar furnace assemblages [40,41]. A total of 12 experiments, whose experimental conditions are reported in Table 2, were considered in this study. The experiments were grouped into two main series carried out at a constant pressure and at different dwell times: experiments of natural starting material series carried out in this study at temperatures of $1225^{\circ} \mathrm{C}$ and dwell times of $0.16,3,6$ and $12 \mathrm{~h}$; experiments of glassy starting material series performed by Bonechi et al. [31] at temperatures of 1250 and $1220{ }^{\circ} \mathrm{C}$, respectively, and dwell times of $0.25,3,6$ and $9 \mathrm{~h}$.

\subsection{Analytical Techniques}

The recovered charges were mounted in epoxy resin, ground flat and polished. Textural features of the recovered samples were analyzed by Scanning Electron Microscopy (SEM) using a FEI Quanta-400 equipped for microanalysis with an EDAX Genesis system at the Earth Sciences Department (Sapienza University, Rome, Italy). At least eight back-scattered electron (BSE) images were acquired for each experimental run in order to accurately measure the number of clinopyroxene nuclei and other mineral 
phases (e.g., [42-44]). Phase compositions were analyzed at the CNR-Istituto di Geologia Ambientale e Geoingegneria (Rome, Italy), with a Cameca SX50 electron microprobe equipped with five wavelength dispersive spectrometers (WDS). Quantitative compositional analyses were performed using $15 \mathrm{kV}$ accelerating voltage and $15 \mathrm{nA}$ beam current. As standards we employed metals for $\mathrm{Mn}$ and $\mathrm{Cr}$, jadeite for $\mathrm{Na}$, wollastonite for $\mathrm{Si}$ and $\mathrm{Ca}$, orthoclase for $\mathrm{K}$, corundum for $\mathrm{Al}$, magnetite for $\mathrm{Fe}$, rutile for $\mathrm{Ti}$ and periclase for $\mathrm{Mg}$. Counting times were $20 \mathrm{~s}$ for elements and $10 \mathrm{~s}$ for backgrounds. Light elements were counted first to prevent loss by volatilization. The PAP correction method was used. Mineral phases were analyzed using a beam diameter of $1 \mu \mathrm{m}$ while for glasses a defocused electron beam of 10 to $15 \mu \mathrm{m}$ was used. The water contents of experimental glasses were estimated from chemical analyses according to the by difference method [45].

\subsection{Growth and Nucleation Rate Calculation}

Crystal dimensions were measured in SEM images by using the measure tool of the Image $\mathrm{J}^{\circledR}$ software (version 1.50i). The maximum growth rate $\left(G_{L}\right)$ values were calculated using a common method reported in literature (e.g., [23,46,47]) based on the dimensions of the largest crystals (i.e., major and minor axes of best fit ellipse):

$$
G_{\mathrm{L}}=(L \cdot W)^{0.5} / \mathrm{t} \times 2
$$

where $L$ and $W$ are the mean length and width, respectively, of the ten largest crystals for each BSE image and $t$ is the duration of the experiments (s). As also observed in the literature, most of the growth often occurs at the beginning of the experiment, since diffusion- or interface controlled growth normally display lower incremental growth rates as the system approaches equilibrium [20,28,30,31,46,48,49]. Therefore, long lasting experiments could show an apparent decrease in $G_{L}$ with increasing time. The nucleation rate of the Cpx crystallized in the runs of natural starting material series were calculated following the procedure reported in Bonechi et al. [31], through which the nucleation rate of Cpx crystallized in glassy starting material series has been calculated. Textural analyses were performed by using Image $]^{\circledR}$ software $[50,51]$ on BSE images from which binary images of each mineral phase were constructed following the procedure of Philpotts and Ague [13]. Manual reconstruction of edges of overlapping crystals was necessary before conversion into binary images. Successively, the data were transferred to the CSDcorrections ${ }^{\circledR}$ software (version 1.6 2018) $[52,53]$ to perform the 2D to 3D conversion and the calculation of CSD plots for each mineral phase. 
Table 2. Experimental run conditions, calculated water contents, phases assemblage and proportions in run products.

\begin{tabular}{|c|c|c|c|c|c|c|c|c|c|}
\hline Run \# & $T\left({ }^{\circ} \mathrm{C}\right)$ & $\begin{array}{c}\mathrm{TCpx}_{\mathrm{L}} \\
\left({ }^{\circ} \mathrm{C}\right)\end{array}$ & $\begin{array}{c}\Delta T_{\text {eff }} \\
\left({ }^{\circ} \mathrm{C}\right)\end{array}$ & $\begin{array}{l}\text { Time } \\
\text { (h) }\end{array}$ & $\begin{array}{l}\mathrm{H}_{2} \mathrm{O}_{\mathrm{i}} \\
(\mathrm{wt} \%)\end{array}$ & Phases & $\begin{array}{c}\mathrm{H}_{2} \mathrm{O}_{\mathrm{f}} \\
(\text { wt. \%) }\end{array}$ & $\Delta \mathbf{r}^{2}$ & $\begin{array}{c}\% \\
\Sigma \mathrm{Fe}^{\S}\end{array}$ \\
\hline \multicolumn{10}{|c|}{ Natural starting material } \\
\hline APR16-3B & 1225 & 1280 & 55 & 0.16 & NWA & $\mathrm{Gl}+\mathrm{Cpx}^{\#}+\mathrm{Ol}^{\#}+\mathrm{Ox}^{\#}$ & 1.77 & & \\
\hline APR16-1C & 1225 & 1280 & 55 & 3 & NWA & $\mathrm{Gl}(94)+\mathrm{Cpx}(6)+\mathrm{Ol}^{\#}+\mathrm{Ox} \#$ & 0.96 & 0.38 & -5 \\
\hline APR16-35 & 1225 & 1280 & 55 & 6 & NWA & $\mathrm{Gl}(96)+\mathrm{Cpx}(4)+\mathrm{Ol}^{\#}$ & 1.70 & 0.14 & -22 \\
\hline APR16-2B & 1225 & 1280 & 55 & 12 & NWA & $\mathrm{Gl}(90)+\mathrm{Cpx}(10)+\mathrm{Ol}^{\#}$ & 2.13 & 0.11 & -35 \\
\hline \multicolumn{10}{|c|}{ Glassy starting material } \\
\hline APR16-C1Aa & 1250 & 1295 & 45 & 0.25 & NWA & $\mathrm{Gl}(97)+\mathrm{Cpx}(3)$ & 1.61 & 1.75 & -7 \\
\hline APR16-C1Ab & 1250 & 1295 & 45 & 3 & NWA & $\mathrm{Gl}(75)+\mathrm{Cpx}(25)$ & 0.90 & 0.62 & -12 \\
\hline APR16-C1Ac & 1250 & 1295 & 45 & 6 & NWA & $\mathrm{Gl}(83)+\mathrm{Cpx}(15)+\mathrm{Ol}(2)$ & 2.03 & 0.83 & -20 \\
\hline APR16-C1Ad & 1250 & 1295 & 45 & 9 & NWA & $\mathrm{Gl}(90)+\mathrm{Cpx}(10)$ & 1.95 & 0.65 & -19 \\
\hline APR16-C2Aa & 1220 & 1270 & 50 & 0.25 & 2 & $\mathrm{Gl}(91)+\mathrm{Cpx}(4)+\mathrm{Ol}(1)+\mathrm{Ox}(4)$ & 1.92 & 0.02 & -25 \\
\hline APR16-C2Ab & 1220 & 1270 & 50 & 3 & 1.9 & $\mathrm{Gl}(68)+\mathrm{Cpx}(23)+\mathrm{Ol}(4)+\mathrm{Plg}(1)+\mathrm{Ox} *$ & 1.56 & 0.66 & -17 \\
\hline APR16-C2Ac & 1220 & 1270 & 50 & 6 & 2.1 & $\mathrm{Gl}(65)+\mathrm{Cpx}(27)+\mathrm{Ol}(5)+\mathrm{Plg}(3)$ & 2.47 & 0.93 & -25 \\
\hline APR16-C2Ad & 1220 & 1270 & 50 & 9 & 1.9 & $\mathrm{Gl}(80)+\mathrm{Cpx}(17)+\mathrm{Ol}(3)+\mathrm{Ox}^{*}$ & 1.30 & 0.25 & -26 \\
\hline \multicolumn{10}{|c|}{$\begin{array}{l}\text { Notes: NWA natural water rock; Gl glass; Cpx clinopyroxene; Ol Olivine; Plg plagioclase; Ox oxide. TCpx } \mathrm{C}_{\mathrm{L}} \text { is } \\
\text { the equilibrium Cpx liquidus temperature }\left({ }^{\circ} \mathrm{C} \text { ) determined on the basis of phase relations experimental data from }\right. \\
\text { Perinelli et al. [32] and on the calculations by using MELTS software }[54,55] . \Delta T_{\text {eff }} \text { is the difference between the } \\
\text { Cpx liquidus temperature and the nominal temperature of the runs. } \mathrm{H}_{2} \mathrm{O}_{\mathrm{i}} \% \text { of water added to the charge. } \mathrm{H}_{2} \mathrm{O}_{\mathrm{f}} \\
\text { as determined by the by-difference method (respect to the total of EMP analyses). } \Sigma \mathrm{r}^{2} \text { values from mass balance } \\
\text { calculation. } \$ \text { Percent of relative Fe loss from starting material based on difference between the starting material and } \\
\text { calculated bulk composition of experiment obtained from mass-balance calculations. }{ }^{*} \text { crystals present in trace; } \\
\# \text { pre-existing crystals. Data for glassy starting material runs from Bonechi et al. [31]. }\end{array}$} \\
\hline
\end{tabular}

\section{Results}

\subsection{Textural Features of the Experimental Runs}

\subsubsection{Natural Starting Material Series}

In APR16-3B run $\left(1225^{\circ} \mathrm{C}, 0.16 \mathrm{~h}\right.$; Figure $\left.1 \mathrm{a}, \mathrm{b}\right)$ the mineral phases occurring in the charge are $\mathrm{Ol}, \mathrm{Cpx}$ and Ox. Olivine size ranges from 10 to $30 \mu \mathrm{m}$ and shows anhedral and subhedral habit. Clinopyroxene is present in small quantity and shows anhedral and subhedral habit with size up to $20 \mu \mathrm{m}$. Oxide is present in trace with size up to $20 \mu \mathrm{m}$ and anhedral shape. The phase assemblage in APR16-1C run (1225 ${ }^{\circ} \mathrm{C}, 3 \mathrm{~h}$; Figure 1c,d) is Cpx, Ol and Ox crystals and large amount of glass. Olivine size ranges from 10 to $30 \mu \mathrm{m}$ and the habit is anhedral. Clinopyroxene (size up to $50 \mu \mathrm{m}$ ) are zoned and show euhedral habit. Oxide is very small in size $(\sim 5 \mu \mathrm{m})$ with subhedral to anhedral shape. In APR16-35 run (1225 ${ }^{\circ} \mathrm{C}, 6$ h; Figure 1e) it was observed the occurrence of Cpx sometimes characterized by inclusion of rounded $\mathrm{Ol}$. Homogeneous and zoned clinopyroxenes show euhedral habit reaching sizes up to $80 \mu \mathrm{m}$. Finally, the phase assemblage of APR16-2B run $\left(1225^{\circ} \mathrm{C}, 12 \mathrm{~h}\right.$; Figure 1f) is Cpx and glass. As seen in the APR16-35 run, rare small olivines ( 10 $\mu \mathrm{m}$ in size) are present as resorbed mineral into Cpx grains. Clinopyroxene are both homogeneous and zoned and show euhedral and subhedral habits. The size of these crystals is up to $90 \mu \mathrm{m}$. By analyzing the textural features of $\mathrm{Ol}$ and $\mathrm{Cpx}$ in the four experiments at $1225^{\circ} \mathrm{C}$ (NWA) it was possible to note that olivine tends to be resorbed from APR16-3B $(0.16 \mathrm{~h})$ to APR16-2B $(12 \mathrm{~h})$ runs, decreasing in size from $40 \mu \mathrm{m}$ to $5 \mu \mathrm{m}$, whereas Cpx increases in size from $20 \mu \mathrm{m}$ up to $80 \mu \mathrm{m}$. Moreover, it is visible a change of the habit of both minerals increasing the duration of the experiments: at $0.16 \mathrm{~h} \mathrm{Ol}$ and Cpx have both anhedral and/or subhedral habit; after three hours $\mathrm{Ol}$ habit becomes anhedral while Cpx shows a noticeable core-rim zoning; after $6 \mathrm{~h}$, instead, anhedral $\mathrm{Ol}$ is almost disappeared, while Cpx has euhedral habit pointing out to a crystal-melt equilibrium. 

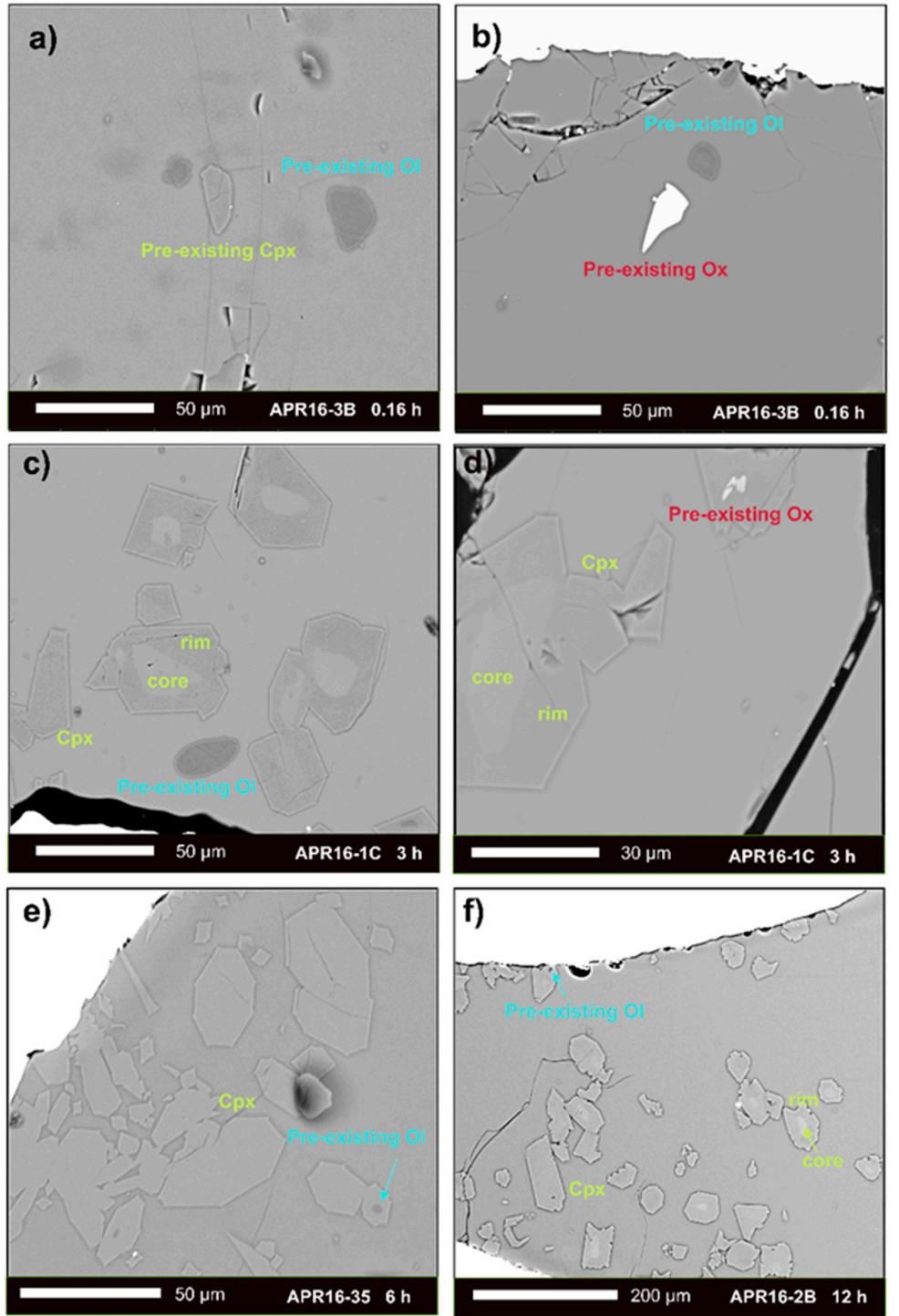

Figure 1. Backscattered SEM image of natural starting material runs: (a,b) APR16-3B run (0.16 h) is characterized by the presence of pre-existing nuclei of $\mathrm{Cpx}, \mathrm{Ol}$ and $\mathrm{Ox}$ with anhedral and subhedral habit; (c,d) APR16-1C run ( $3 \mathrm{~h}$ ) is characterized by the presence of both zoned Cpx grown on the pre-exiting nuclei and new Cpx, pre-existing Ol and Ox; (e) APR16-35 run (6 h) shows euhedral Cpx with homogenous and zoned compositions, while $\mathrm{Ol}$ is present as resorbing crystal inside Cpx; (f) APR16-2B run (12 h) is characterized by zoned and homogenous $\mathrm{Cpx}$ and resorbed $\mathrm{Ol}$ included in Cpx crystals.

\subsubsection{Glassy Starting Material Series}

Textural features of these two series are described in detail in Bonechi et al. [32]. Here a briefly description of the fundamental aspects is reported. In the runs of APR16-C1A $\left(1250{ }^{\circ} \mathrm{C}\right)$ series the dominant phase is Cpx (Table 2), whose habit and sizes vary with time: subhedral with sizes of $5 \mu \mathrm{m}$ in the shortest run (APR16-C1Aa; $0.25 \mathrm{~h}$ ), and euhedral with sizes up to $15 \mu \mathrm{m}$ in the longest run (APR16-C1Ad; $9 \mathrm{~h}$ ). In the APR16-C1Ac run $(6 \mathrm{~h}) \mathrm{Ol}$, characterized by euhedral habit and sizes of $\sim 10 \mu \mathrm{m}$, occurs together with the Cpx. The mineral phases crystallized in APR16-C2A $\left(1220^{\circ} \mathrm{C}\right)$ series are $\mathrm{Cpx}+\mathrm{Ol}+\mathrm{Plg}+\mathrm{Ox}$ (Table 2). In these runs $\mathrm{Cpx}$ and $\mathrm{Ol}$ are ubiquitous, while Plg occurs only in the runs at 3 and $6 \mathrm{~h}$ and $\mathrm{Ox}$ is absent in the run at $6 \mathrm{~h}$. Clinopyroxene has subhedral habit in the run with the shortest duration and euhedral in the other runs, with sizes between $\sim 10$ and $20 \mu \mathrm{m}$. Olivine and Plg crystals are euhedral with sizes of $\sim 15$ and $\sim 40 \mu \mathrm{m}$, respectively. 


\subsection{Phases Composition}

Chemical compositions of $\mathrm{Cpx}$, glass and $\mathrm{Ol}$ of natural starting material and glassy starting material runs are reported in Table S1 in the Supplementary Material. Chemical compositions of the other phases crystallized in glassy starting material runs are reported in Bonechi et al. [31].

\subsubsection{Natural Starting Material Series}

Clinopyroxene. Clinopyroxene crystals in natural starting material runs are classified as diopsides $\left(\mathrm{Wo}_{41-49} \mathrm{En}_{44-50} \mathrm{Fs}_{4-9}\right)$ according to the classification scheme of Morimoto et al. [56]. Some clinopyroxene crystals show core-rim compositional variations. For example, in APR16-1C and APR16-2B runs the $\mathrm{Cpx}$ core is characterized by higher $\mathrm{CaO}$ and lower $\mathrm{Al}_{2} \mathrm{O}_{3}$ and $\mathrm{Na}_{2} \mathrm{O}$ content than those of the rim (Table S1 in the Supplementary Material). As highlighted in the previous sections, textural evidences suggest mineral-melt disequilibrium in the short experiments ( $\leq 3 \mathrm{~h}$ runs) and also the chemistry in term of clinopyroxene-liquid Fe-Mg exchange coefficient, calculated by using the formula $(\mathrm{FeO} / \mathrm{MgO})^{\mathrm{Cpx}} /(\mathrm{FeO} / \mathrm{MgO})^{\mathrm{liq}}$, is quite in agreement with textural evidences. The ${ }^{\mathrm{Cpx}-\mathrm{liq}} K_{\mathrm{DFe}-\mathrm{Mg}}$ value in the APR16-3B run $(0.16 \mathrm{~h})$ is 0.43 , in APR16-1C run $(3 \mathrm{~h})$ is $0.28 \pm 0.02$ for the core and $0.33 \pm$ 0.02 for the rim, in APR16-35 run $(6 \mathrm{~h})$ is $0.33 \pm 0.06$ for the core and $0.32 \pm 0.02$ for the rim, and in APR16-2B run $(12 \mathrm{~h})$ is $0.56 \pm 0.21$ and $0.47 \pm 0.02$ for the core and for the rim, respectively. According to Putirka [57], the calculated $K_{\mathrm{D}}$ value for APR16-35 and APR16-1C indicate equilibrium between clinopyroxene and liquid, whereas only in the shortest (APR16-3B) and in the longest (APR16-2B) experiment the chemical Cpx-liquid equilibrium has been not achieved (Figure 2). Notably, the $K_{\mathrm{D}}$ calculated for the APR16-2B run (12 h) could be due to the significant loss of Fe in the melt related to the long experimental dwell time.

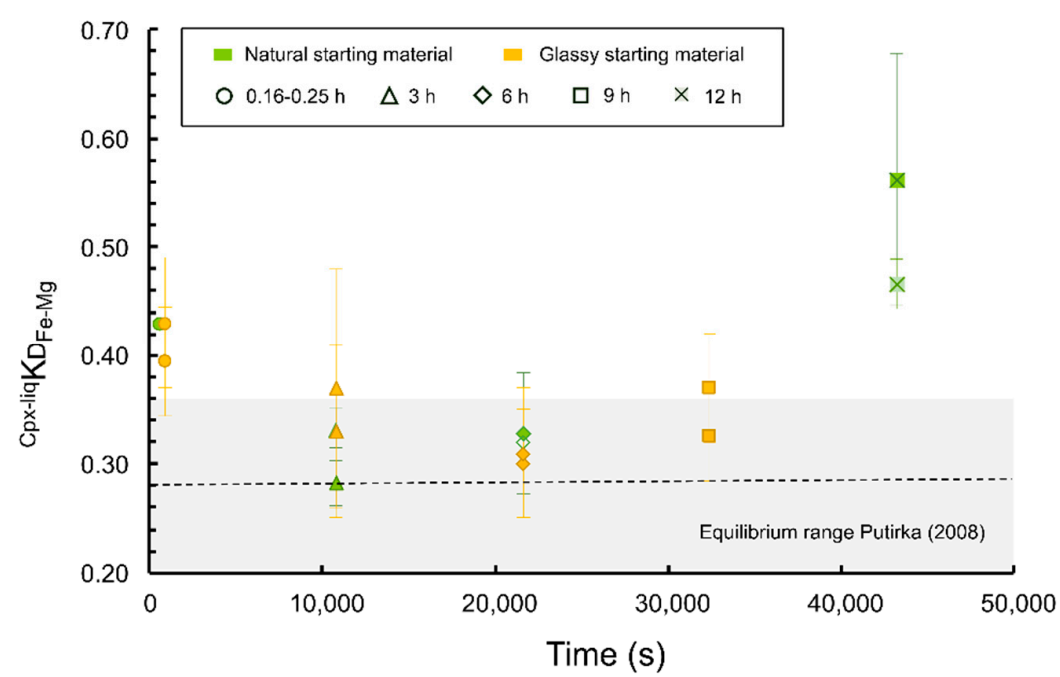

Figure 2. Relation between $K_{\mathrm{D}}(\mathrm{Fe}-\mathrm{Mg}) \mathrm{Cpx}$-liq and time (s). The duration of each run is indicated with different symbols: circle for 0.16 and $0.25 \mathrm{~h}$ runs, triangle for $3 \mathrm{~h}$ runs, diamond for $6 \mathrm{~h}$ runs, square for $9 \mathrm{~h}$ runs and square with internal cross for $12 \mathrm{~h}$ run. Series are indicated with different colors: green for natural starting material, and yellow for glassy starting material. For natural starting material runs are used empty symbols for Cpx rims and full symbols for Cpx cores. The grey field represents the equilibrium range according to Putirka [57], while the dotted line represents the average $K_{\mathrm{D}}$ value for Cpx $(0.28 \pm 0.08 ;[57])$.

Olivine. Olivine crystals show a variation in their forsteritic content from $\sim 91$ (APR16-35; $6 \mathrm{~h}$ ) to 87 (APR16-3B; $0.16 \mathrm{~h}$ ) decreasing the experimental time. These values suggest a dissolution of $\mathrm{Ol}$ that becomes more restitic increasing the duration of the experiments. Moreover, the forsteritic content of $\mathrm{Ol}$ present in the APR16-3B run $\left(\mathrm{Fo}_{87}\right)$, that is the same value reported by $\mathrm{D}^{\prime}$ Antonio et al. [34] for 
natural olivines in APR16 sample, confirms that they are remnant of the natural starting material rather than phases crystallized during the experiment.

\subsubsection{Glassy Starting Material Series}

Clinopyroxene. Clinopyroxene crystals are augitic $\left(\mathrm{Wo}_{42} \mathrm{En}_{41} \mathrm{Fs}_{18}\right)$ and diopsidic $\left(\mathrm{Wo}_{47} \mathrm{En}_{43} \mathrm{Fs}_{10}\right)$ in composition according to the classification scheme of Morimoto et al. [56]. Generally, the Mg\# of $\mathrm{Cpx}$ (calculated as the molar $\mathrm{MgO} /\left(\mathrm{MgO}+\mathrm{FeO}_{\text {tot }}\right)$ ratio) varies between 0.76 and 0.88 , whilst the $\mathrm{Mg \#}$ of glass varies between 0.52 and 0.77 . The Fe-Mg distribution coefficients between $\mathrm{Cpx}$ and melt $\left(K_{\mathrm{D}}(\mathrm{Fe}-\mathrm{Mg})^{\mathrm{Cpx}-\mathrm{liq}}=\mathrm{Fe}_{\mathrm{Cpx}} \times \mathrm{Mg}_{\text {liq }} / \mathrm{Mg}_{\mathrm{Cpx}} \times \mathrm{Fe}_{\text {liq }}\right.$, calculated assuming all $\mathrm{Fe}$ as $\mathrm{Fe}^{2+}$ in both phases $)$, varies between $0.39 \pm 0.05$ and $0.30 \pm 0.05$ for APR16-C1A runs, and between $0.43 \pm 0.06$ and $0.31 \pm$ 0.06 for APR16-C2A runs. As illustrated in Figure 2, all the shortest runs deviate significantly from the equilibrium range $\left(K_{\mathrm{D}}(\mathrm{Fe}-\mathrm{Mg})^{\mathrm{Cpx}-\mathrm{liq}}=0.28 \pm 0.08\right.$ according to Putirka [57]), whereas runs of $3 \mathrm{~h}$ or more progressively reach equilibrium conditions. As previously observed for the longest run of natural starting material series (APR16-2B; $12 \mathrm{~h}$ ), the slightly deviation from the equilibrium range of the $K_{\mathrm{D}}$ calculated in the run at $9 \mathrm{~h}$, could be due to the loss of Fe in the melt related to the long experimental dwell time.

Other phases: Oxide crystals are generally spinels (APR16-C1Ab, APR16-C2Aa and APR16-C2Ab) and hercynites (APR16-C2Ab). Olivine is present in the run APR16-C1Ac with a forsteritic content of $\mathrm{Fo}_{89}$ and in the runs APR16-C1Aa, APR16-C1Ab and APR16-C1Ac with compositions of Fo $86-90$. Plagioclase grains occurring only in the runs APR16-C2Ab and APR16-C2Ac are bytownitic and labradoritic in composition.

\subsection{Textural and Chemical Evidences of the Occurrence of Pre-Existing Nuclei}

In the runs of natural starting material series, the use of a natural starting material containing pre-existing nuclei results in growth around pre-existing crystals. Textural and chemical evidences suggest that the Cpx observed in the APR16-3B run $\left(0.16 \mathrm{~h}, 1225^{\circ} \mathrm{C}\right)$ are pre-existing Cpx, while in the other runs the pre-existing crystals constitute the cores of the zoned Cpx. As regards textural features, the scarce abundance of the Cpx crystals observed in APR16-3B run (Figure 1a) and their anhedral and subhedral habits with size of $\sim 10-20 \mu \mathrm{m}$, suggest that they are not crystallized during the experiments but are relic of the phenocrysts present in the natural starting material. Indeed, in comparison, the Cpx crystallized in APR16-C1Aa run $\left(0.25 \mathrm{~h}, 1250^{\circ} \mathrm{C}\right)$ obtained using the glassy starting material, are more abundant and show subhedral and euhedral habit with maximum size of $10 \mu \mathrm{m}$. As regards chemical evidences, the $\mathrm{Al}^{\mathrm{IV}}$ vs Al ${ }^{\mathrm{VI}}$ and $\mathrm{Na}$ vs $\mathrm{Al}^{\mathrm{VI}}$ diagrams (Figure 3), in which both natural starting material and glassy starting material series and some natural Cpx belonging to the same deposits of the APR16 sample [58] are reported, allowed to identify the presence of pre-existing nuclei. In particular, the $\mathrm{Al}^{\mathrm{IV}}$ vs $\mathrm{Al}^{\mathrm{VI}}$ diagram represents a good indicator of pressure conditions at which clinopyroxene crystallizes, due to the preference of Al to occupy tetrahedral and octahedral sites at high $T$ and $P$, respectively $[59,60]$. Moreover, it is important to stress that the Al concentration in Cpx can be influenced not only by pressure, but also by kinetic effects (e.g., [49]). Similar function has the diagram in which $\mathrm{Al}^{\mathrm{VI}}$ is plotted versus $\mathrm{Na}$, suggested to be a pressure-sensitive element [57]. As possible to see in these diagrams, the Cpx of the APR16-3B run and the cores of the zoned Cpx of the APR16-1C, APR16-35 and APR16-2B runs fall in the field corresponding to a pressure $\leq 0.5 \mathrm{GPa}$ as well as the natural Cpx. Conversely, the rim of natural starting material series and the Cpx of the glassy starting material series fall in the field corresponding to a pressure $\geq 0.7 \mathrm{GPa}$. Moreover, both $\mathrm{Al}^{\mathrm{IV}}$ and $\mathrm{Na}$ content allowed to discriminate between pre-existing Cpx and Cpx crystallized during the experiments, as shown also in Figure 4. In particular, in the diagrams of Figure 4 ( $\mathrm{Al}^{\mathrm{IV}}$ vs $\mathrm{Mg \#}$ and $\mathrm{Na}$ vs $\left.\mathrm{Mg \#}\right)$ these two kinds of Cpx are separated by a red dotted lines, drawn in correspondence of the higher $\mathrm{Al}^{\mathrm{VI}}$ and Na values (0.06 and $0.02 \mathrm{apfu}$, respectively) of natural Cpx [58]. The pre-existing nuclei, indeed, are located near the red dotted lines while the rims and the Cpx crystallized in the glassy starting material series are located far from the lines, showing higher $\mathrm{Al}^{\mathrm{VI}}$ and $\mathrm{Na}$ values. The Cpx cores of 
APR16-35 (6 h) and APR16-2B (12 h) runs, however, are slightly different from the cores of APR16-3B and APR16-1C runs. This difference could be due to the loss of Fe occurred in their melt during the experiments but also to kinetic effects, as stated by Pontesilli et al. [49]. These authors, indeed, observed that in time-series experiments, but also in experiments performed at constant dwell time, compositional changes in Cpx crystals are function of dwell time, according to the cation exchange $(\mathrm{Si}+\mathrm{Mg}) \rightarrow\left({ }^{\mathrm{T}} \mathrm{Al}\right.$ and $\left.\mathrm{Fe}^{3+}\right)$.
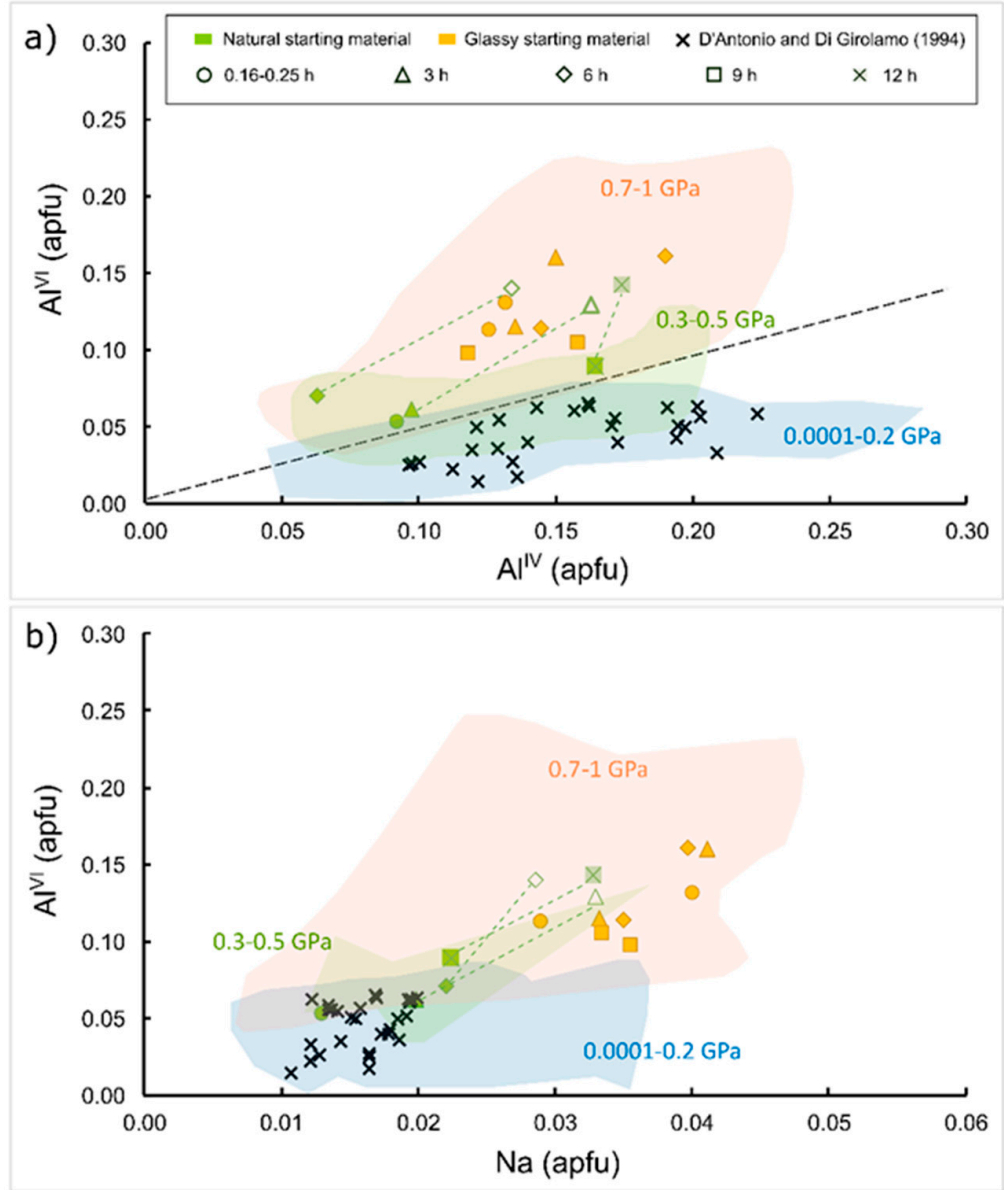

Figure 3. $\mathrm{Al}^{\mathrm{IV}}$ vs $\mathrm{Al}^{\mathrm{VI}}$ (a) and $\mathrm{Na}_{\mathrm{vs} \mathrm{Al}} \mathrm{VI}$ (b) diagrams. Literature data (black crosses) are from D'Antonio and Di Girolamo [58]. The new forming Cpx can be distinguished from the pre-existing nuclei: the former fall in the high-pressure field $(P>0.7 \mathrm{GPa})$, while the latter in the low pressure one $(P \leq 0.5 \mathrm{GPa})$. The black dotted line bounding the fields of high-low pressure $\mathrm{Cpx}$ is an arbitrary limit drawn on the basis of results of experiments on APR16 composition at 0.2, 0.4 (low-P field) and 0.8 GPa (high-P field) [32].The green dotted lines, instead, connect Cpx core and rim. Series are indicated with different colors: green for natural starting material, and yellow for glassy starting material. The duration of each run is indicated with different symbols: circle for 0.16 and $0.25 \mathrm{~h}$ runs, triangle for $3 \mathrm{~h}$ runs, diamond for $6 \mathrm{~h}$ runs, square for $9 \mathrm{~h}$ runs and square with internal cross for $12 \mathrm{~h}$ run. In natural starting material series empty symbols indicate $\mathrm{Cpx}$ rim, while full symbols indicate Cpx cores. Colored field represents literature experimental data [32]. Error bars are smaller than symbol size. 

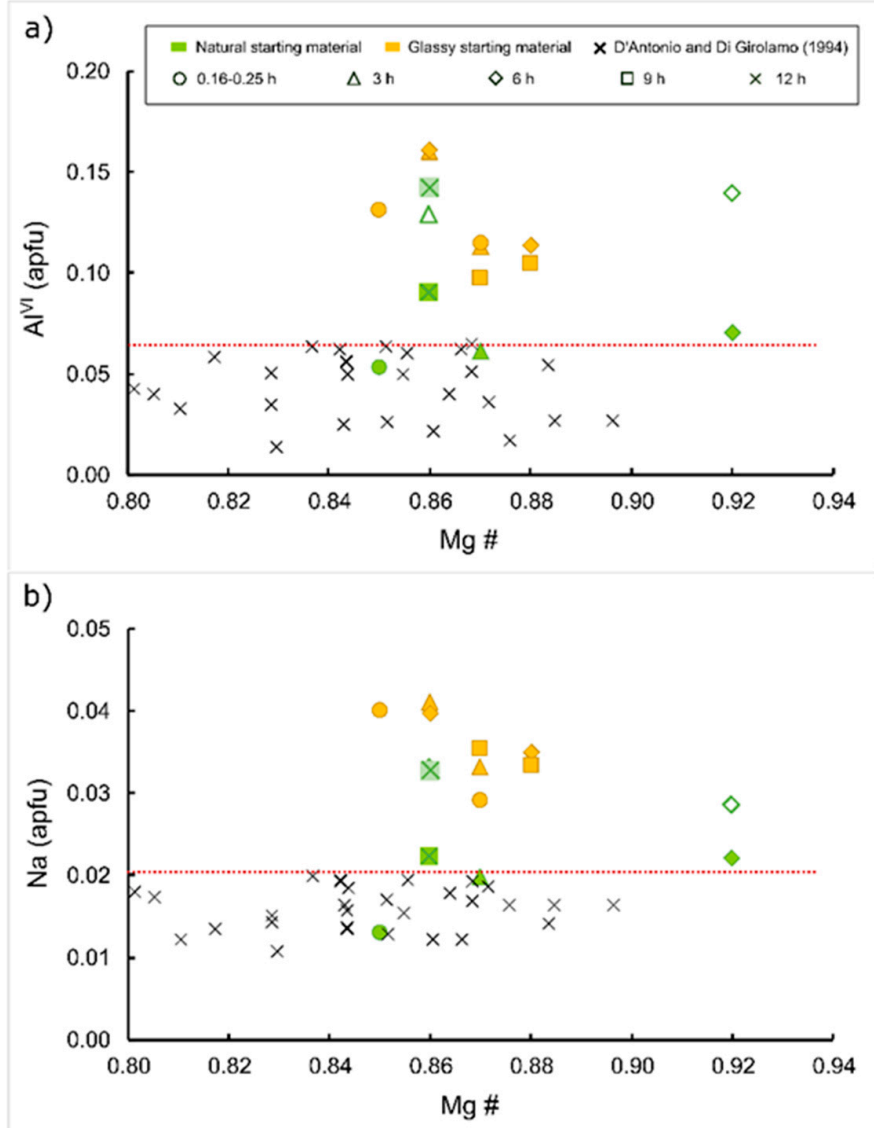

Figure 4. $\mathrm{Al}^{\mathrm{VI}}$ (apfu) vs $\mathrm{Mg \#} \mathrm{(a)} \mathrm{and} \mathrm{Na}(\mathrm{apfu})$ vs $\mathrm{Mg \#}(\mathbf{b})$. Symbols are as in Figure 3. The red dotted line allows to discriminate between pre-existing nuclei and new forming crystals. This is an arbitrary limit drawn on the basis of the obtained results of this study and literature data from D'Antonio and Di Girolamo [58].

\subsection{Clinopyroxene Growth and Nucleation Rates}

Maximum growth rates determined for clinopyroxene are reported in Table 3. Figure 5 illustrates the relation between a) crystal size $(L)$ and experimental time, and b) crystal growth rate $\left(G_{\mathrm{L}}\right)$ and experiment time. In both series it was possible to observe an increase in crystal size with increasing time, while the growth rates decrease by about an order of magnitude with increasing duration of the experiments. In the runs of natural starting material series the $G_{\mathrm{L}}$ decreases from $\sim 2 \times 10^{-7}$ to $\sim 6 \times 10^{-8} \mathrm{~cm} \cdot \mathrm{s}^{-1}$ as duration increases from 3 to $12 \mathrm{~h}$, while in the runs of glassy starting material series the $G_{\mathrm{L}}$ decreases from $\sim 3 \times 10^{-7}$ to $\sim 2 \times 10^{-8} \mathrm{~cm} \cdot \mathrm{s}^{-1}$ as duration increases from 0.25 to $9 \mathrm{~h}$ [31]. Moreover, it is possible to see that both the sizes and the $G_{\mathrm{L}}$ values of natural starting material runs are higher than those of glassy starting material ones. The growth rates obtained for the two series are comparable with those available in literature for basaltic and trachybasaltic compositions [48,49,61-64]. In particular, the growth rates of the glassy starting material runs show values in agreement with those obtained in the static experiments of Burkhard [62] on re-heated anhydrous basalt (dwell times of 22-576 h, $T=930-990^{\circ} \mathrm{C}$ and $P=1 \mathrm{~atm}$ ) and of Orlando et al. [48] on anhydrous trachybasalt (dwell times of $3-40 \mathrm{~h}, T=1170{ }^{\circ} \mathrm{C}, P=1 \mathrm{~atm}$ and $\Delta T=20^{\circ} \mathrm{C}$ ). The growth rates of the natural starting material run, instead, are an order of magnitude higher than these latter. Their values, indeed, are similar to those obtained in the dynamic experiments of Pontesilli et al. [49] on a anhydrous and hydrous trachybasalt (dwell times of $0.5-24 \mathrm{~h}, T=1100{ }^{\circ} \mathrm{C}, P=400 \mathrm{MPa}$ and $\Delta T=80-120^{\circ} \mathrm{C}$ ), of Shea and Hammer [17] on a hydrous basaltic-andesite (dwell times of $12-48 \mathrm{~h}, \mathrm{~T}=995-1025^{\circ} \mathrm{C}$, $P=65-150 \mathrm{MPa}$ and $\Delta T=52-155^{\circ} \mathrm{C}$ ) and of Baker [64] on a trachybasalt (dwell times of 3.5-14 $\mathrm{h}$, 
$T=1150^{\circ} \mathrm{C}, P=1000 \mathrm{MPa}$ and $\Delta T=75^{\circ} \mathrm{C}$ ). Finally, growth rates of both natural and glassy starting material runs show higher values than those obtained by Burkhard [61] on re-heated Hawaiian basalt ( $\sim 0.01-7 \mathrm{~h}$ of crystal residence times) and by Oze and Winter [63] on tholeiitic basalt ( $\sim .04-9 \mathrm{~h}$ of crystal residence times).

Table 3. Calculated growth rate values for clinopyroxene.

\begin{tabular}{|c|c|c|c|c|c|c|c|c|c|}
\hline Run \# & $T\left({ }^{\circ} \mathrm{C}\right)$ & Time (s) & $\begin{array}{c}\mathrm{H}_{2} \mathrm{O}_{\mathrm{f}} \\
\text { (wt. \%) }\end{array}$ & $L(\mathrm{~cm})$ & $\begin{array}{l}\text { St. dev. } \\
\text { (cm) }\end{array}$ & $W(\mathrm{~cm})$ & $\begin{array}{l}\text { St. dev. } \\
\text { (cm) }\end{array}$ & $G_{\mathrm{L}}\left(\mathrm{cm} \cdot \mathrm{s}^{-1}\right)$ & $\begin{array}{l}\text { St. dev. } \\
\left(\mathrm{cm} \cdot \mathrm{s}^{-1}\right)\end{array}$ \\
\hline \multicolumn{10}{|c|}{ Natural starting material } \\
\hline APR16-3B & 1225 & 600 & 1.77 & $1.55 \times 10^{-3}$ & $6.3 \times 10^{-4}$ & $9.00 \times 10^{-4}$ & $1.4 \times 10^{-4}$ & - & - \\
\hline APR16-1C & 1225 & 10,800 & 0.96 & $4.37 \times 10^{-3}$ & $5.9 \times 10^{-4}$ & $2.70 \times 10^{-3}$ & $6.5 \times 10^{-4}$ & $1.59 \times 10^{-7}$ & $3.0 \times 10^{-8}$ \\
\hline APR16-35 & 1225 & 21,600 & 1.70 & $4.64 \times 10^{-3}$ & $1.5 \times 10^{-3}$ & $2.83 \times 10^{-3}$ & $5.8 \times 10^{-4}$ & $8.34 \times 10^{-8}$ & $1.9 \times 10^{-8}$ \\
\hline APR16-2B & 1225 & 43,200 & 2.13 & $6.01 \times 10^{-3}$ & $2.0 \times 10^{-3}$ & $4.16 \times 10^{-3}$ & $8.0 \times 10^{-4}$ & $5.76 \times 10^{-8}$ & $1.4 \times 10^{-8}$ \\
\hline \multicolumn{10}{|c|}{ Glassy starting material } \\
\hline APR16-C1 & Aa1250 & 900 & 1.61 & $6.48 \times 10^{-4}$ & $4.4 \times 10^{-5}$ & $3.13 \times 10^{-4}$ & $6.8 \times 10^{-5}$ & $2.50 \times 10^{-7}$ & $2.9 \times 10^{-8}$ \\
\hline APR16-C1 & $\mathrm{Ab} 1250$ & 10,800 & 2.33 & $1.17 \times 10^{-3}$ & $2.1 \times 10^{-4}$ & $5.30 \times 10^{-4}$ & $9.8 \times 10^{-5}$ & $3.64 \times 10^{-8}$ & $6.8 \times 10^{-9}$ \\
\hline APR16-C1 & Ac1250 & 21,600 & 2.03 & $1.35 \times 10^{-3}$ & $1.5 \times 10^{-4}$ & $5.86 \times 10^{-4}$ & $1.5 \times 10^{-4}$ & $2.06 \times 10^{-8}$ & $2.8 \times 10^{-9}$ \\
\hline APR16-C1 & Ad1250 & 32,400 & 1.95 & $1.43 \times 10^{-3}$ & $2.1 \times 10^{-4}$ & $8.78 \times 10^{-4}$ & $1.2 \times 10^{-4}$ & $1.73 \times 10^{-8}$ & $2.0 \times 10^{-9}$ \\
\hline APR16-C2 & Aa1220 & 900 & 1.92 & $8.40 \times 10^{-4}$ & $1.1 \times 10^{-4}$ & $4.05 \times 10^{-4}$ & $9.2 \times 10^{-5}$ & $3.24 \times 10^{-7}$ & $5.2 \times 10^{-8}$ \\
\hline APR16-C2 & $\mathrm{Ab} 1220$ & 10,800 & 1.56 & $1.07 \times 10^{-3}$ & $2.3 \times 10^{-4}$ & $4.04 \times 10^{-4}$ & $6.5 \times 10^{-5}$ & $3.04 \times 10^{-8}$ & $3.9 \times 10^{-9}$ \\
\hline APR16-C2 & Ac1220 & 21,600 & 2.47 & $1.68 \times 10^{-3}$ & $1.3 \times 10^{-4}$ & $7.93 \times 10^{-4}$ & $3.0 \times 10^{-4}$ & $2.67 \times 10^{-8}$ & $5.1 \times 10^{-9}$ \\
\hline APR16-C2 & Ad1220 & 32,400 & 1.30 & $1.70 \times 10^{-3}$ & $1.6 \times 10^{-4}$ & $9.22 \times 10^{-4}$ & $2.0 \times 10^{-4}$ & $1.93 \times 10^{-8}$ & $2.2 \times 10^{-9}$ \\
\hline
\end{tabular}

Notes: NWA natural water rock; $\mathrm{H}_{2} \mathrm{O}_{\mathrm{f}}$ as determined by the by-difference calculation method (respect to the total of EMP analyses). $L$ and $W$ are the length and the width of the crystals. $G_{L}$ is the calculated growth rate. St. dev. Standard deviation. Data for glassy starting material runs from Bonechi et al. [31].

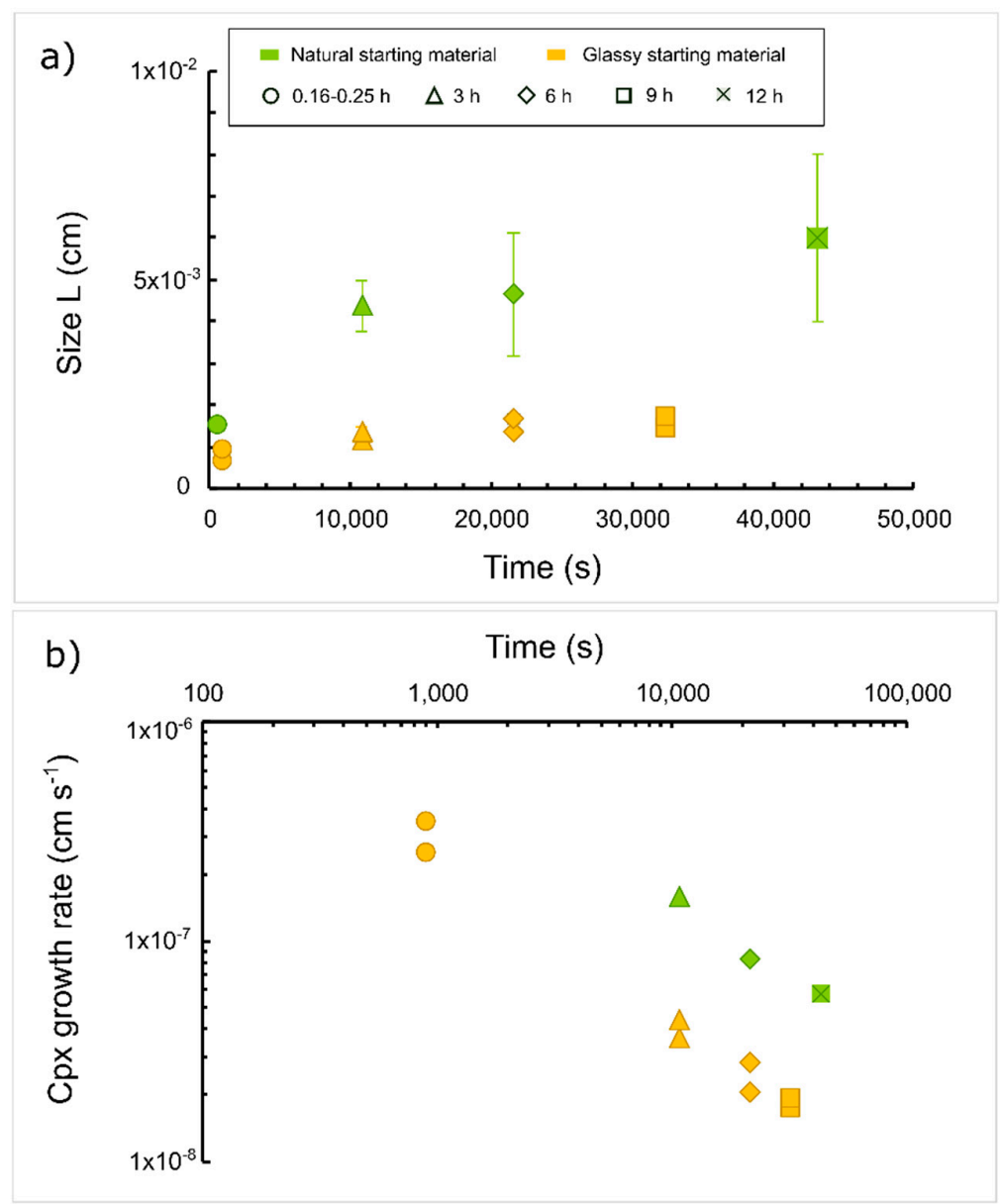

Figure 5. Relation between (a) Cpx size $(L)$ and experimental time, and (b) Cpx growth rate $\left(G_{\mathrm{L}}\right)$ and experimental time. Symbols are as in Figure 2. Error bars are not shown when they are inside the symbols. 
The nucleation rate $(J)$ determined for clinopyroxene are reported in Table 4 . Calculated nucleation rates for natural starting material runs vary between $10^{2}$ and $10 \mathrm{~mm}^{-3} \cdot \mathrm{s}^{-1}$ from 3 to $12 \mathrm{~h}$, while for the glassy starting material runs vary between $10^{5}$ and $10^{3} \mathrm{~mm}^{-3} \cdot \mathrm{s}^{-1}$ from the shortest $(0.25 \mathrm{~h})$ to the longest $(9 \mathrm{~h})$ durations, respectively. Figures 6 and 7 a show the nucleation rate vs time and the nucleation rate vs undercooling $(\Delta T)$ diagrams, respectively. In both diagrams it is possible to note that Cpx nucleation rates of natural starting material runs are lower than those of glassy starting material runs. In Figure 6, $J$ tends to decrease increasing dwell time in all the series: in particular, the nucleation seems to decrease up to $\sim 3 \mathrm{~h}$, after which it remains quite constant. In Figure $7 \mathrm{a}$, instead, the nucleation rate decreases increasing the $\Delta T$.

Table 4. Calculated nucleation rate values for clinopyroxene.

\begin{tabular}{|c|c|c|c|c|c|}
\hline Run \# & $T\left({ }^{\circ} \mathrm{C}\right)$ & Time (s) & $\operatorname{Ln} n_{0}\left(\mathrm{~mm}^{-4}\right)$ & $n_{0}\left(\mathrm{~mm}^{-4}\right)$ & $J\left(\mathrm{~mm}^{-3} \cdot \mathrm{s}^{-1}\right)$ \\
\hline \multicolumn{6}{|c|}{ Natural starting material } \\
\hline APR16-1C & $1225^{\circ}$ & 10,800 & 19.6 & $3.25 \times 10^{8}$ & $5.17 \times 10^{2}$ \\
\hline APR16-35 & 1225 & 21,600 & 17.86 & $5.71 \times 10^{7}$ & $4.76 \times 10^{1}$ \\
\hline APR16-2B & 1225 & 43,200 & 18.02 & $6.70 \times 10^{7}$ & $3.86 \times 10^{1}$ \\
\hline \multicolumn{6}{|c|}{ Glassy starting material } \\
\hline APR16-C1Aa & 1250 & 900 & 25.78 & $1.57 \times 10^{11}$ & $3.93 \times 10^{5}$ \\
\hline $\mathrm{APR} 16-\mathrm{C} 1 \mathrm{Ab}$ & 1250 & 10,800 & 26.84 & $4.53 \times 10^{11}$ & $1.65 \times 10^{5}$ \\
\hline APR16-C1Ac & 1250 & 21,600 & 24.8 & $5.90 \times 10^{10}$ & $1.21 \times 10^{4}$ \\
\hline APR16-C1Ad & 1250 & 32,400 & 25.05 & $7.57 \times 10^{10}$ & $1.31 \times 10^{4}$ \\
\hline APR16-C2Aa & 1220 & 900 & 22.4 & $5.35 \times 10^{9}$ & $1.85 \times 10^{4}$ \\
\hline APR16-C2Ab & 1220 & 10,800 & 24.13 & $3.00 \times 10^{10}$ & $1.32 \times 10^{4}$ \\
\hline APR16-C2Ac & 1220 & 21,600 & 23.09 & $1.06 \times 10^{10}$ & $2.96 \times 10^{3}$ \\
\hline APR16-C2Ad & 1220 & 32,400 & 23.13 & $1.10 \times 10^{10}$ & $2.13 \times 10^{3}$ \\
\hline
\end{tabular}

Notes: $\operatorname{Ln} n_{0}$ is the natural logarithm of nucleation density, $n_{0}$ is the nucleation density and $J$ is the nucleation rate. Nucleation density and rate were calculated trough the equations: $n_{0}=\exp \left(\ln \left(n_{0}\right)\right)$ and $J=n_{0} \times G$, respectively. $\operatorname{Ln} n_{0}$ as derived by CSD Corrections 1.6 program [52,53]. Data for glassy starting material runs from Bonechi et al. [31].

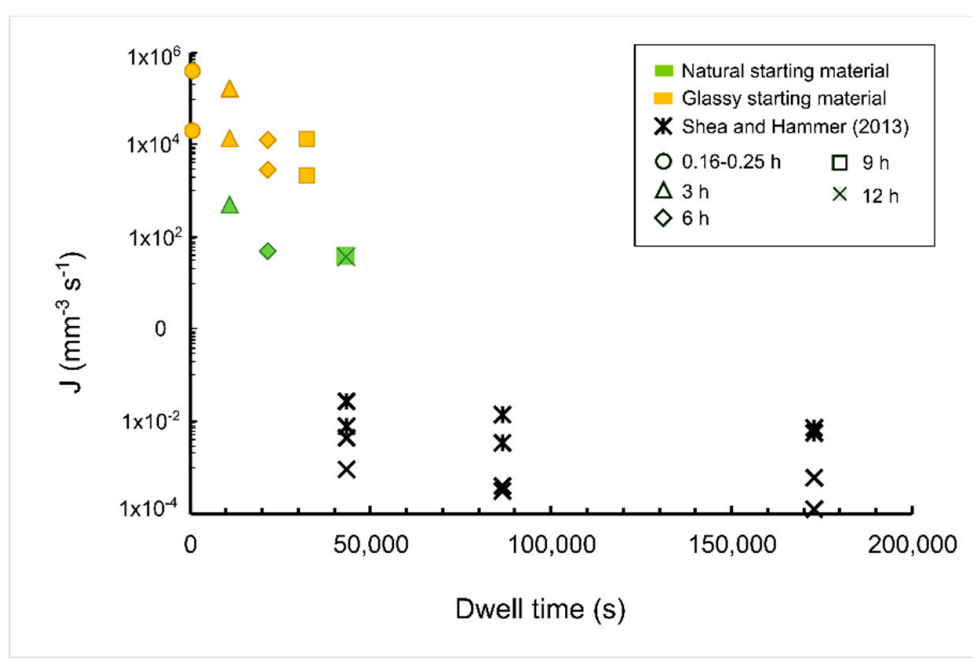

Figure 6. Relation between the nucleation rate $(J)$ and the experimental time. Symbols are as in Figure 2. Black asterisks indicate the single step cooling runs $\left(\Delta T_{\text {eff }}=52-82^{\circ} \mathrm{C}\right)$ of Shea and Hammer [17]. 

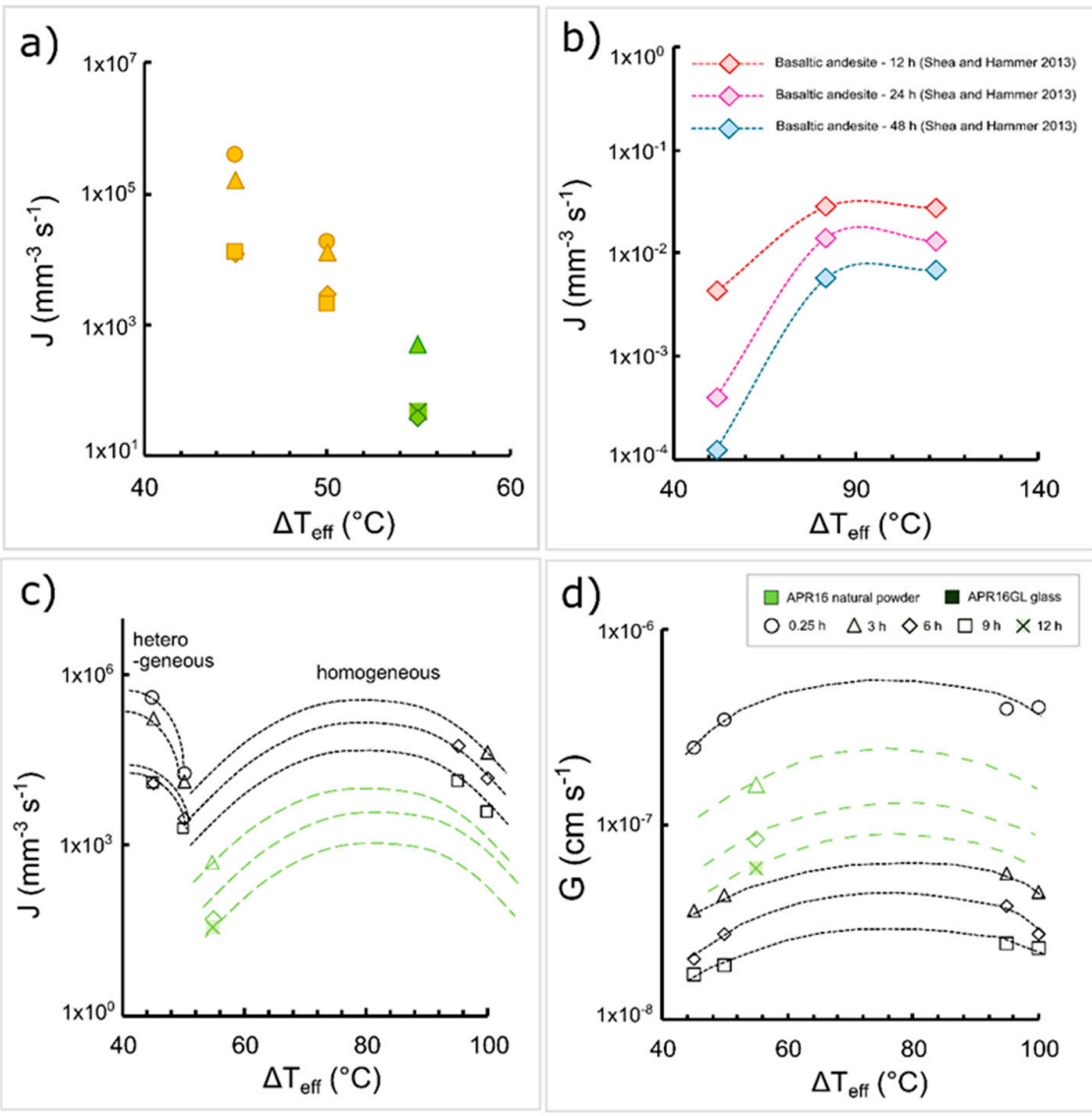

Figure 7. Variation of $(\mathbf{a}-\mathbf{c})$ the nucleation rate $(J)$ with the undercooling $\left(\Delta T_{\text {eff }}\right)$ and $(\mathbf{d})$ the growth rate $\left(G_{L}\right)$ with the undercooling $\left(\Delta T_{\text {eff }}\right)$. In Figure 7 a are reported the runs of natural starting material series (in green), and glassy starting material series (in yellow); symbols are as in Figure 2. Figure 7b shows the single step cooling runs of Shea and Hammer [17] for comparison; colors indicate different duration of the runs: in red the $12 \mathrm{~h}$-runs, in purple the $24 \mathrm{~h}$-runs and in blue the $48 \mathrm{~h}$-runs. Figure $7 \mathrm{c}$, d show the runs investigated in this study $\left(\Delta T_{\text {eff }}<60^{\circ} \mathrm{C}\right)$ and those of Bonechi et al. [31] $\left(\Delta T_{\text {eff }}>60^{\circ} \mathrm{C}\right)$; symbols are as in Figure 2. Dotted lines indicate the hypothetical variation of $J$ with $\Delta T_{\text {eff }}$ (Figure $7 \mathrm{c}$ ) and of $G$ with $\Delta T_{\text {eff }}$ (Figure $7 \mathrm{~d}$ ). Green lines indicate runs obtained using natural starting material while black ones run obtained using vitrified starting material.

\section{Discussion}

\subsection{Influence of Pre-Existing Crystals on Nucleation and Growth Rate}

Crystallization implies two successive processes: nucleation and crystal growth. While a rapid cooling suppresses the nucleation process favoring the formation of a glass, a moderate to slow cooling, instead, allows nucleation that can be either homogeneous or heterogeneous [26]. In the homogeneous nucleation case nuclei have the same probability to form spontaneously in any part of the melt, whereas in the second case nucleation occurs preferentially on pre-existing surfaces (e.g., [26,27,65-70]). As stated by Špillar and Dolejš [15], in presence of pre-existing nuclei the interfacial energy between the nucleating phase and the pre-existing nuclei is lower than that between the nucleating phase and the melt because of lesser number of broken bonds between two solid phases. The pre-existing nuclei, therefore, represent a site of energetically favorable nucleation, which is statistically preferred due to the structural similarity between the substrates (e.g., [8,25,27]). As observed by Vetere et al. [25,26], the structural similarities between the pre-existing nuclei and the nucleating phases concentrate the supply of chemical elements in the liquid surrounding the new growing crystals, limiting in this way the formation of new nucleation sites. Moreover, according to Masotta et al. [20], element diffusivity in 
the melt also play a fundamental role in determining either new nucleation or growth on pre-existing nuclei. This influence of the pre-existing crystals on the nucleation has been observed also in this study. Firstly, the Cpx crystallized in natural starting material series are present as big crystals (up to $\sim 80 \mu \mathrm{m}$ ) in smaller quantities than those crystallized in glassy starting material one, that are small in size (up to $\sim 20 \mu \mathrm{m}$ ) and very abundant (Figures 1 and 3a and Table 2). Moreover, in the diagrams of Figure 6 it is possible to see that the Cpx of natural starting material runs show nucleation rates lower than those of glassy starting material runs. The presence of these pre-existing crystals, thus, influencing the nucleation rate, consequently, also affects the growth rate. As shown in Figure 5b, indeed, the Cpx growth rates of natural starting material runs are higher than those of the other series. Since the series were performed with similar time and water content conditions, the only different parameters able to affect the growth rate are temperature and undercooling (e.g., [30,31]). However, neither can justify the higher growth rate of natural starting material runs, since both temperature and undercooling $\left(\Delta T=T_{\text {liquidus }}-T_{\text {experiment }}\right)$ of natural starting material series $\left(1225^{\circ} \mathrm{C}\right.$ and $55^{\circ} \mathrm{C}$, respectively) are quite similar to those of glassy starting material series $\left(1250-1220^{\circ} \mathrm{C}\right.$ and $45-50{ }^{\circ} \mathrm{C}$, respectively). Indeed, considering how the nucleation should vary with the undercooling, in absence of pre-existing crystals, the nucleation values should be slightly lower than those measured for lower $\Delta T$ (i.e., $45-50^{\circ} \mathrm{C}$ ) but not so different as those measured in natural starting material runs ( $\sim 3$ order of magnitude of difference; Figure 7a). The same interpretation is applicable to the growth rate (Figure 7d): indeed, in absence of pre-existing nuclei, the growth rate should be slightly higher than those measured for lower $\Delta T$ (i.e., $45-50^{\circ} \mathrm{C}$ ) but with a difference lower than an order of magnitude. The influence of pre-existing crystals on nucleation and growth rate has also been observed for plagioclase crystals in the work of Arzilli et al. [28], comparing the natural rhyolite of Hammer and Rutherford [23] with the vitrified rhyolite of Mollard et al. [71]. Therefore, the different values of nucleation and growth rates in the natural starting material series seems to be linked to the presence of pre-existing nuclei rather than to the different undercooling.

\subsection{Influence of Time on Nucleation and Growth Rates}

Time is an important factor since it plays a crucial role in the crystallization processes of silicate melts (e.g., [23,28,46,72]). As shown in Figure 6, the runs of this study show a decrease of the Cpx nucleation rate with increasing the duration of the experiments as well as those (single-step cooling runs) of Shea and Hammer [17]. $J$ is relatively high during the initial nucleation event (0.25 and $3 \mathrm{~h})$, from $10^{4}$ to $10^{5} \mathrm{~mm}^{-3} \cdot \mathrm{s}^{-1}$, and rapidly decreases increasing the dwell time (6 and $\left.9 \mathrm{~h}\right)$ remaining quite constant $\left(10^{3}\right.$ and $10^{4} \mathrm{~mm}^{-3} \cdot \mathrm{s}^{-1}$ for glassy starting material runs, respectively). This suggests that the main event of nucleation occurred within the first three hours of the experiment, probably in the first minutes at the beginning of the experiment as observed by $\mathrm{Ni}$ et al. [73] for a basaltic composition through in situ experiments.

According to the results of Bonechi et al. [31], the Cpx growth rate calculated for the natural starting material series follow the trend of the glassy starting material one, varying by an order of magnitude between the runs with the shortest and those with the longest durations (Figure 5b), in agreement with what has been observed in other studies available in literature (e.g., $[17,48,49,61,74])$. In particular, starting from a dwell time $\geq 3 \mathrm{~h}$, the runs begin to achieve conditions close to the textural equilibrium, at which point an overall decay of the growth rate occurs $[20,21,48]$. The influence of time on crystal growth rate, indeed, results to be strictly related to the equilibration time of the growing phases, as observed by previous studies (e.g., [28,31,43,46,48]).

\subsection{Influence of Undercooling on Nucleation and Growth Rates}

Arzilli et al. [28] comparing plagioclase nucleation rates in a variety of experimental studies on water-saturated compositions ranging from basaltic through rhyolitic, noted that nucleation rates of 8-h runs in basaltic melts increase with increasing $\Delta T_{\text {eff }}$ (i.e., the difference between the phase liquidus temperature and the nominal temperature of the runs), whereas the 1-h runs show an opposite trend, 
because the nucleation process was not able to be accomplished due to the limited experimental dwell time. The authors, indeed, suggest that for the same $\Delta T_{\text {eff }}$ the nucleation could be completed within $2 \mathrm{~h}$. The increase of the nucleation rate with the undercooling has also been observed for clinopyroxene by Masotta et al. [20] in a trachybasaltic melt in long-lasting runs (dwell time of $24 \mathrm{~h}$ ). Although in this study it was possible to calculate the nucleation rates at $0.25 \mathrm{~h}$ only for low undercoolings, it is reasonable to assume that the $\leq 3-\mathrm{h}$ runs behave like the 1-h runs of Arzilli et al. [28], in accordance with what stated above. As shown in Figure $7 c$, the nucleation rate decreases with increasing the undercooling up to $50^{\circ} \mathrm{C}$ while for higher undercooling the nucleation first increases (up to $100{ }^{\circ} \mathrm{C}$ ) and then decreases, similarly to the trend of the runs of Shea and Hammer [17] (Figure 7b). At effective degrees of undercooling $\leq 50{ }^{\circ} \mathrm{C}$, indeed, most phases fail to nucleate significantly probably due to the dominance of crystal growth [8,17], rather than to a nucleation lag or incubation period as typically considered [75-77]. Moreover, according to Shea and Hammer [17], at low undercoolings $\left(\leq 50{ }^{\circ} \mathrm{C}\right)$ it is possible to hypothesize the occurrence of a heterogeneous nucleation due to the high energy barrier required by homogeneous nucleation. The lack of the latter process in the natural starting material runs is related to the presence of pre-existing nuclei in the starting melt, that favor growth over nucleation. For undercoolings $>50{ }^{\circ} \mathrm{C}$ (data from Bonechi et al. [31]), instead, the nucleation has a bell shape suggesting that it probably occurs homogeneously (Figure 7c).

As regards the growth rate, it occurred both on pre-existing crystals as well as on new forming nuclei during the experiments. As shown in Figure 7d, to the growth rate follows a bell-shaped trend with increasing the undercooling, in agreement with what observed by previous studies (e.g., [17,28]). Moreover, the Cpx growth rates of the run with pre-existing nuclei (natural starting material series) are higher than those of the other runs (glassy starting material series) at similar $T$ and time conditions, according to what previously observed for the nucleation rate (i.e., pre-existing nuclei in the starting melt favor growth over nucleation).

\subsection{Application}

In Bonechi et al. [31], data of Cpx growth rates have been combined with thermobarometric data of natural Cpx (SCE and SOG samples) in order to provide an estimate of deep-level ascent rate for CFVD primitive magmas. In particular, they assumed that a deep episode of magmatic crystallization occurred at low undercooling, a condition verified by CSD investigations of SCE and SOG samples that highlighted the presence of three main Cpx population: larger phenocrysts (sizes $\sim 0.32 \mathrm{~mm}$ ), smaller phenocrysts and microlites (sizes $<0.32 \mathrm{~mm}$ ). The range of temperatures and pressures of crystallization estimated for the larger population of Cpx are between $1141-1178{ }^{\circ} \mathrm{C}$ and 0.7-0.9 GPa (20-25 km of depth assuming an average crustal density of $2.8 \mathrm{~g} / \mathrm{cm}^{3}$ ), suggest together with CSD analysis that this population formed during a crystallization stage at deep level. According to the approach of Armienti et al. [78], for a $\Delta T$ of $37{ }^{\circ} \mathrm{C}\left(\Delta T=1178-1141{ }^{\circ} \mathrm{C}\right)$, a $\Delta L$ of $\sim 0.3 \mathrm{~cm}$ and a growth rate of $2 \times 10^{-8} \mathrm{~cm} \cdot \mathrm{s}^{-1}$, the cooling rate during the ascent of Procida K-basaltic magmas was estimated to be $0.3 \times 10^{-5}{ }^{\circ} \mathrm{C} / \mathrm{s}$. This value, combined with the $\mathrm{d} P / \mathrm{d} T$ from thermobarometry, provided a deep-level ascent velocity of $\sim 0.5 \times 10^{-4} \mathrm{~m} \cdot \mathrm{s}^{-1}$. In this work using the same crystallization parameters but the growth rate obtained for the natural starting material series, influenced by the presence of pre-existing nuclei $\left(1.2 \times 10^{-7} \mathrm{~cm} \cdot \mathrm{s}^{-1}\right)$, a deep-level ascent velocity of $\sim 6 \times 10^{-4} \mathrm{~m} \cdot \mathrm{s}^{-1} \mathrm{was}$ obtained. However, the $\mathrm{Ol} / \mathrm{Cpx}$ ratio $(\sim 1)$ of the SCE and SOG samples suggests, in accordance with the experimental phase relations at $0.2-0.8 \mathrm{GPa}$ [79], that primitive magmas of Procida pond at relatively shallow level before the Solchiaro hydromagmatic eruption. This is validated by barometric estimation on the smaller phenocrysts, whose crystallization occurred at $0.3-0.5 \mathrm{GPa}$ (8-14 km of depth; [31]). Therefore, the assessed residence time for the larger $C p x$ population (i.e., at least 5 months for a $G_{L}$ of $2 \times 10^{-8} \mathrm{~cm} \cdot \mathrm{s}^{-1}$ and 1 months for a $G_{\mathrm{L}}$ of $1.2 \times 10^{-7} \mathrm{~cm} \cdot \mathrm{s}^{-1}$ ) multiplied for the magma volume erupted from the CFVD tuff ring $\left(0.1-1 \mathrm{~km}^{3}\right.$; e.g., [80]) could represent the minimum recharge rate of the large magmatic reservoir, whose top is situated in the CFVD at about $8 \mathrm{~km}$ of depth [81-88]. Considering the mass balance model of Fedi et al. [84], according to which the source of the Campania Active Volcanic 
Area has a total volume of about $40,000 \mathrm{~km}^{3}$, an estimated recharge rate of $0.2-2 \mathrm{~km}^{3} \cdot \mathrm{year}^{-1}$ (absence of pre-existing nuclei) or 1-10 $\mathrm{km}^{3} \cdot$ year $^{-1}$ (in presence of pre-existing nuclei) suggests that a deep reservoir of primitive parental magma similar to those had feeding the Campanian Ignimbrite eruption (39 ka), could be formed in a time interval ranging from $10^{4}$ to $10^{5}$ years (absence of pre-existing nuclei) or $10^{3}$ to $10^{4}$ years (presence of pre-existing nuclei).

In the case of Solchiaro eruption, the absence of plagioclase phenocrysts and the primitive composition of scoriae indicate that the magma does not stop at $8 \mathrm{~km}$ or shallower reservoirs but continue its ascent, going directly to feed the hydromagmatic eruption [35]. Moreover, the composition of the Cpx populations with $L<0.32 \mathrm{~mm}$ in the SOG and SCE scoriae indicates that the late stage of crystallization of the Solchiaro magma takes places in conditions of disequilibrium probably caused by the eruptive regime of ascent. Thus, by taking a grain growth of $\sim 0.32 \mathrm{~mm}$ and a $G_{\mathrm{L}}$ of $2 \times 10^{-7} \mathrm{~cm} \cdot \mathrm{s}^{-1}$, that as indicated by Bonechi et al. [31] experiments it is suitable for disequilibrium conditions of Cpx-crystallization, the resulting minimum clinopyroxene residence time during the ascent from $\sim 8 \mathrm{~km}$ of depth is on the order of 2 days and it results to be very similar to the residence time estimated by Piochi et al. [89], Calzolaio et al. [90] and Arzilli et al. [91] in their works on feldspar bearing products of Monte Nuovo eruption (1538). Noteworthy, this time interval is equivalent to that during which occurred the more intense precursor phenomena (i.e., earthquakes, uplift, lowering, increase of the flow of wells) of the Monte Nuovo eruption [92], that is the last of the CFVD and whose VEI $(\leq 4)$ is comparable to that of Solchiaro eruption [80].

\section{Conclusions}

This study provides constraints on the effect of pre-existing nuclei on clinopyroxene growth and nucleation rates. In particular, the growth rates calculated in the run performed using natural starting material with pre-existing nuclei are higher than those calculated in the runs performed using the vitrified starting material, while the nucleation rates show the opposite behavior with lower values for the run containing pre-existing nuclei. These differences are due to the structural similarities between the pre-existing nuclei and the nucleating phases that concentrate the supply of chemical elements in the liquid surrounding the new growing crystals, limiting in this way the formation of new nucleation sites.

Moreover, the influence of time and undercooling on growth and nucleation rate has been investigated. Concerning the time, regardless of the starting material, for all the series both growth and nucleation rates decrease with increasing dwell time from $\sim 10^{-7}$ to $\sim 10^{-8} \mathrm{~cm} \cdot \mathrm{s}^{-1}$ and from $10^{5}$ to $10 \mathrm{~mm}^{-3} \cdot \mathrm{s}^{-1}$, respectively, as time decreases from 0.16 to $12 \mathrm{~h}$.

In regard to the undercooling, instead, the nucleation rate decreases with increasing the undercooling up to $50^{\circ} \mathrm{C}$ while for higher undercooling the nucleation first increases (up to $100{ }^{\circ} \mathrm{C}$ ) and then decreases. At $\Delta T_{\text {eff }} \leq 50^{\circ} \mathrm{C}$, indeed, most phases fail to nucleate significantly probably due to the dominance of crystal growth, as it is possible to observe for the runs containing pre-existing nuclei. For $\Delta T_{\text {eff }}>50{ }^{\circ} \mathrm{C}$, instead, the nucleation has a bell shape as that observed for the growth rate.

Finally, the application of the calculated growth rate, combined with the thermobarometric estimates and the crystal size analysis of natural samples from Procida island (CFVD), allow to estimate the recharge rate of the of the large magmatic reservoir, whose top has been located in the CFVD at about $8 \mathrm{~km}$ of depth. These data $\left(0.2-2 \mathrm{~km}^{3} \cdot \mathrm{year}^{-1}\right.$ in absence of pre-existing nuclei or $1-10 \mathrm{~km}^{3} \cdot \mathrm{year}^{-1}$ in presence of pre-existing nuclei) suggests that a deep reservoir of primitive parental magma similar to those had feeding the Campanian Ignimbrite eruption ( $39 \mathrm{ka}$ ), could be formed in a time interval ranging from $10^{4}$ to $10^{5}$ years (absence of pre-existing nuclei) or $10^{3}$ to $10^{4}$ years (presence of pre-existing nuclei).

Supplementary Materials: The following are available online at http://www.mdpi.com/2075-163X/10/3/234/s1, Table S1: Electron-microprobe analyses of clinopyroxene, glass and olivine of the experimental runs. 
Funding: This research has been conducted with the financial support of the HP-HT Laboratory of the Earth Sciences Department, Sapienza University of Rome and and with the financial support of the project 000047_19_MEDI_GAETA_FONDI 2019.

Acknowledgments: I would like to thank the anonymous Reviewers for their comments helpful in improving the manuscript. I thank Luca Ziberna (BGI Bayreuth) for preparing APR16GL sample, M. Albano (CNR-IGAG) for help in electronic backscattered images and M. Serracino (CNR-IGAG) for help in EMP analyses. I also thanks M. Gaeta and C. Perinelli for their support in the preparation of this work.

Conflicts of Interest: The authors declare no conflict of interest. The funders had no role in the design of the study; in the collection, analyses, or interpretation of data; in the writing of the manuscript, or in the decision to publish the results.

\section{References}

1. Tiller, W.A. On the cross-pollenation of crystallization ideas between metallurgy and geology. Phys. Chem. Miner. 1977, 2, 125-151. [CrossRef]

2. Davis, M.J.; Ihinger, P.D. Effects of thermal history on crystal nucleation in silicate melt: Numerical simulations. J. Geophys. Res. Solid Earth 2002, 107, ECV-8. [CrossRef]

3. Fenn, P.M. The nucleation and growth of alkali feldspars from hydrous melts. Can. Mineral. 1977, 15, 135-161.

4. Swanson, S.E. Relation of nucleation and crystal-growth rate to the development of granitic textures. Am. Mineral. 1977, 62, 966-978.

5. Davis, M.J.; Ihinger, P.D.; Lasaga, A.C. Influence of water on nucleation kinetics in silicate melt. J. Non. Cryst. Solids 1997, 219, 62-69. [CrossRef]

6. Muncill, G.E.; Lasaga, A.C. Crystal-growth kinetics of plagioclase in igneous systems: Isothermal $\mathrm{H}_{2} \mathrm{O}$-saturated experiments and extension of a growth model to complex silicate melts. Am. Mineral. 1988, 73, 982-992.

7. Cashman, C.V.; Marsh, B.D. Crystal size distribution (CSD) in rocks and the kinetics and dynamics of crystallisation. Contrib. Mineral. Petrol. 1988, 99, 292-305. [CrossRef]

8. Lofgren, G.E. Effect of heterogeneous nucleation on basaltic textures: A dynamic crystallization study. J. Petrol. 1983, 24, 229-255. [CrossRef]

9. Kirkpatrick, R.J. Nucleation and growth of plagioclase, Makaopuhi and Alae lava lakes, Kilauea Volcano, Hawaii. Geol. Soc. Am. Bull. 1977, 88, 78-84. [CrossRef]

10. Mishima, N.; Ota, R.; Wakasugi, T.; Fukunaga, J. Analysis of crystallization behavior in $\mathrm{Li}_{2} \mathrm{O} \cdot 2 \mathrm{SiO}_{2}$ glass by DTA method based on a liquid model. J. Non. Cryst. Solids 1996, 197, 19-24. [CrossRef]

11. Uda, S. Influence of unit cluster size on nucleation rate of $\mathrm{Li}_{2} \mathrm{~B}_{4} \mathrm{O}_{7}$ melt. J. Cryst. Growth 1994, 140, $128-138$. [CrossRef]

12. Berkebile, C.A.; Dowty, E. Nucleation in laboratory charges of basaltic composition. Am. Mineral. 1982, 67, 886-899.

13. Philpotts, A.; Ague, J. Principles of Igneous and Metamorphic Petrology; Cambridge University Press: Cambridge, UK, 2009.

14. Hammer, J.E.; Sharp, T.G.; Wessel, P. Heterogeneous nucleation and epitaxial crystal growth of magmatic minerals. Geology 2010, 38, 367-370. [CrossRef]

15. Špillar, V.; Dolejš, D. Heterogeneous nucleation as the predominant mode of crystallization in natural magmas: Numerical model and implications for crystal-melt interaction. Contrib. Mineral. Petrol. 2015, 169, 1-16. [CrossRef]

16. Pichavant, M.; Costa, F.; Burgisser, A.; Scaillet, B.; Martel, C.; Poussineau, S. Equilibration scales in silicic to intermediate magmas implications for experimental studies. J. Petrol. 2007, 48, 1955-1972. [CrossRef]

17. Shea, T.; Hammer, J.E. Kinetics of cooling- and decompression-induced crystallization in hydrous mafic-intermediate magmas. J. Volcanol. Geotherm. Res. 2013, 260, 127-145. [CrossRef]

18. Walker, D.; Powell, M.A.; Lofgren, G.E.; Hays, J.F. Dynamic crystallization of a eucrite basalt. In Proceedings of the Lunar and Planetary Science Conference Proceedings, Houston, TX, USA, 13-17 March 1978; Volume 1, pp. 1369-1391.

19. Pupier, E.; Duchene, S.; Toplis, M.J. Experimental quantification of plagioclase crystal size distribution during cooling of a basaltic liquid. Contrib. Mineral. Petrol. 2008, 155, 555-570. [CrossRef] 
20. Masotta, M.; Pontesilli, A.; Mollo, S.; Armienti, P.; Ubide, T.; Nazzari, M.; Scarlato, P. The role of undercooling during clinopyroxene growth in trachybasaltic magmas: Insights on magma decompression and cooling at Mt. Etna volcano. Geochim. Cosmochim. Acta 2020, 268, 258-276. [CrossRef]

21. Hammer, J.E. Experimental Studies of the Kinetics and Energetics of Magma Crystallization. Rev. Mineral. Geochem. 2008, 69, 9-59. [CrossRef]

22. Lesher, C.E.; Cashman, K.V.; Mayfield, J.D. Kinetic controls on crystallization of Tertiary North Atlantic basalt and implications for the emplacement and cooling history of lava at site 989, Southeast Greenland Rifted Margin. Larsen, H.C., Duncan, R.A., Eds.; Ocean Drilling Program: College Station, TX, USA, 1999; pp. 135-148.

23. Hammer, J.E.; Rutherford, M.J. An experimental study of the kinetics of decompression-induced crystallization in silicic melt. J. Geophys. Res. 2002, 107, 2021. [CrossRef]

24. Shea, T.; Larsen, J.F.; Gurioli, L.; Hammer, J.E.; Houghton, B.F.; Cioni, R. Leucite crystals: Surviving witnesses of magmatic processes preceding the 79AD eruption at Vesuvius, Italy. Earth Planet. Sci. Lett. 2009, 281, 88-98. [CrossRef]

25. Vetere, F.; Iezzi, G.; Behrens, H.; Cavallo, A.; Misiti, V.; Dietrich, M.; Knipping, J.; Ventura, G.; Mollo, S. Intrinsic solidification behaviour of basaltic to rhyolitic melts: A cooling rate experimental study. Chem. Geol. 2013, 354, 233-242. [CrossRef]

26. Vetere, F.; Iezzi, G.; Behrens, H.; Holtz, F.; Ventura, G.; Misiti, V.; Cavallo, A.; Mollo, S.; Dietrich, M. Glass forming ability and crystallisation behaviour of sub-alkaline silicate melts. Earth Sci. Rev. 2015, 150, $25-44$. [CrossRef]

27. Mollo, S.; Iezzi, G.; Ventura, G.; Cavallo, A.; Scarlato, P. Heterogeneous nucleation mechanisms and formation of metastable phase assemblages induced by different crystalline seeds in a rapidly cooled andesitic melt. J. Non. Cryst. Solids 2012, 358, 1624-1628. [CrossRef]

28. Arzilli, F.; Agostini, C.; Landi, P.; Fortunati, A.; Mancini, L.; Carroll, M.R. Plagioclase nucleation and growth kinetics in a hydrous basaltic melt by decompression experiments. Contrib. Mineral. Petrol. 2015, 170, 55. [CrossRef]

29. Bonechi, B.; Perinelli, C.; Gaeta, M.; Tecchiato, V.; Granati, S.F. Experimental constraints on amphibole stability in primitive alkaline and calc-alkaline magmas. Period. Mineral. 2017, 86, 231-245.

30. Bonechi, B.; Perinelli, C.; Gaeta, M.; Tecchiato, V.; Fabbrizio, A. Amphibole growth from a primitive alkaline basalt at $0.8 \mathrm{GPa}$ : Time-dependent compositional evolution, growth rate and competition with clinopyroxene. Lithos 2020, 354, 105272. [CrossRef]

31. Bonechi, B.; Perinelli, C.; Gaeta, M. Clinopyroxene growth rates at high-pressure: Constraints on magma recharge of the deep reservoir of the Campi Flegrei Volcanic District (south Italy). Bull. Volcanol. 2020, 82, 5. [CrossRef]

32. Perinelli, C.; Gaeta, M.; Bonechi, B.; Granati, S.F.; Freda, C.; D’Antonio, M.; Stagno, V.; Sicola, S.; Romano, C. Effect of water on the phase relations of primitive K-basalts: Implications for high-pressure differentiation in the Phlegraean Volcanic District magmatic system. Lithos 2019, 342, 530-541.

33. Morabito, S.; Petrosino, P.; Milia, A.; Sprovieri, M.; Tamburrino, S. A multidisciplinary approach for reconstructing the stratigraphic framework of the last $40 \mathrm{ka}$ in a bathyal area of the eastern Tyrrhenian Sea. Glob. Planet. Chang. 2014, 123, 121-138. [CrossRef]

34. D'Antonio, M.; Civetta, L.; Di Girolamo, P. Mantle source heterogeneity in the Campanian Region (South Italy) as inferred from geochemical and isotopic features of mafic volcanic rocks with shoshonitic affinity. Mineral. Petrol. 1999, 67, 163-192. [CrossRef]

35. De Astis, G.; Pappalardo, L.; Piochi, M. Procida volcanic history: New insights into the evolution of the Phlegraean Volcanic District (Campania region, Italy). Bull. Volcanol. 2004, 66, 622-641. [CrossRef]

36. Johannes, W.; Bell, P.M.; Mao, H.K.; Boettcher, A.L.; Chipman, D.W.; Hays, J.F.; Newton, R.C.; Seifert, F. An interlaboratory comparison of piston-cylinder pressure calibration using the albite-breakdown reaction. Contrib. Mineral. Petrol. 1971, 32, 24-38. [CrossRef]

37. Presnall, D.C.; Dixon, S.A.; Dixon, J.R.; O’Donnell, T.H.; Brenner, N.L.; Schrock, R.L.; Dycus, D.W. Liquidus phase relations on the join diopside-forsterite-anorthite from $1 \mathrm{~atm}$ to $20 \mathrm{kbar}$ : Their bearing on the generation and crystallization of basaltic magma. Contrib. Mineral. Petrol. 1978, 66, 203-220. [CrossRef]

38. Kress, V.C.; Carmichael, I.S.E. The compressibility of silicate liquids containing $\mathrm{Fe}_{2} \mathrm{O}_{3}$ and the effect of composition, temperature, oxygen fugacity and pressure on their redox states. Contrib. Mineral. Petrol. 1991, 108, 82-92. [CrossRef] 
39. Toplis, M.J. The thermodynamics of iron and magnesium partitioning between olivine and liquid: Criteria for assessing and predicting equilibrium in natural and experimental systems. Contrib. Mineral. Petrol. 2005, 149, 22-39. [CrossRef]

40. Conte, A.M.; Dolfi, D.; Gaeta, M.; Misiti, V.; Mollo, S.; Perinelli, C. Experimental constraints on evolution of leucite-basanite magma at 1 and 10-4 GPa: Implications for parental compositions of Roman high-potassium magmas. Eur. J. Mineral. 2009, 21, 763-782. [CrossRef]

41. Weaver, S.L.; Wallace, P.J.; Johnston, A.D. Experimental constraints on the origins of primitive potassic lavas from the Trans-Mexican Volcanic Belt. Contrib. Mineral. Petrol. 2013, 166, 825-843. [CrossRef]

42. Clarke, A.B.; Stephens, S.; Teasdale, R.; Sparks, R.S.J.; Diller, K. Petrologic constraints on the decompression history of magma prior to Vulcanian explosions at the Soufrière Hills volcano, Montserrat. J. Volcanol. Geotherm. Res. 2007, 161, 261-274. [CrossRef]

43. Couch, S. Experimental investigation of crystallization kinetics in a haplogranite system. Am. Mineral. 2003, 88, 1471-1485. [CrossRef]

44. Hammer, J.E.; Cashman, K.V.; Voight, B. Magmatic processes revealed by textural and compositional trends in Merapi dome lavas. J. Volcanol. Geotherm. Res. 2000, 100, 165-192. [CrossRef]

45. Devine, J.D.; Gardner, J.E.; Brack, H.P.; Layne, G.D.; Rutherford, M.J. Comparison of microanalytical methods for estimating $\mathrm{H}_{2} \mathrm{O}$ contents of silicic volcanic glasses. Am. Mineral. 1995, 80, 319-328. [CrossRef]

46. Couch, S.; Sparks, R.S.J.; Carroll, M.R. The kinetics of degassing-induced crystallization at Soufriere Hills Volcano, Montserrat. J. Petrol. 2003, 44, 1477-1502. [CrossRef]

47. Iezzi, G.; Mollo, S.; Torresi, G.; Ventura, G.; Cavallo, A.; Scarlato, P. Experimental solidification of an andesitic melt by cooling. Chem. Geol. 2011, 283, 261-273. [CrossRef]

48. Orlando, A.; D'Orazio, M.; Armienti, P.; Borrini, D. Experimental determination of plagioclase and clinopyroxene crystal growth rates in an anhydrous trachybasalt from Mt Etna (Italy). Eur. J. Mineral. 2008, 20, 653-664. [CrossRef]

49. Pontesilli, A.; Masotta, M.; Nazzari, M.; Mollo, S.; Armienti, P.; Scarlato, P.; Brenna, M. Crystallization kinetics of clinopyroxene and titanomagnetite growing from a trachybasaltic melt: New insights from isothermal time-series experiments. Chem. Geol. 2019, 510, 113-129. [CrossRef]

50. Abramoff, M.D.; Magalhães, P.J.; Ram, S.J. Image Processing with ImageJ. Biophotonics Intern. 2004, 11, 36-42.

51. Schneider, C.A.; Rasband, W.S.; Eliceiri, K.W. NIH Image to ImageJ: 25 years of image analysis. Nat. Methods 2012, 9, 671-675. [CrossRef]

52. Higgins, D.M. Measurement of crystal size distributions. Am. Mineral. 2000, 85, 1105-1116. [CrossRef]

53. Higgins, M.D. Closure in crystal size distributions (CSD), verification of CSD calculations, and the significance of CSD fans. Am. Mineral. 2002, 87, 1242-1243. [CrossRef]

54. Ghiorso, M.S.; Sack, R.O. Chemical mass transfer in magmatic processes IV. A revised and internally consistent thermodynamic model for the interpolation and extrapolation of liquid-solid equilibria in magmatic systems at elevated temperatures and pressures. Contrib. Mineral. Petrol. 1995, 119, 197-212. [CrossRef]

55. Asimow, P.; Ghiorso, M.S. Algorithmic modifications extending MELTS to calculate subsolidus phase relations. Am. Mineral. 1998, 83, 1127-1132. [CrossRef]

56. Morimoto, N.; Fabries, J.; Ferguson, A.K.; Ginzburg, I.V.; Ross, M.; Seifert, F.A.; Zussman, J.; Aoki, K.; Gottardi, G. Nomenclature of pyroxenes Subcommittee. Am. Mineral. 1998, 73, 1123-1133.

57. Putirka, K.D. Thermometers and barometers for volcanic systems. In Minerals, Inclusions and Volcanic Processes; Putirka, K.D., Tepley, F.J., III, Eds.; Mineralogical Society of America: Chantilly, VA, USA, 2008; Volume 69, pp. 61-120. ISBN 1529-6466.

58. D'Antonio, M.; Di Girolamo, P. Petrological and geochemical study of mafic shoshonitic volcanics from Procida-Vivara and Ventotene Islands (Campanian Region, South Italy). Acta Vulcanol. 1994, 5, 69-80.

59. Herzberg, C.T. Pyroxene geothermometry and geobarometry: Experimental and thermodynamic evaluation of some subsolidus phase relations involving pyroxenes in the system $\mathrm{CaO}-\mathrm{MgO}-\mathrm{Al}_{2} \mathrm{O}_{3}-\mathrm{SiO}_{2}$. Geochim. Cosmochim. Acta 1978, 42, 945-957. [CrossRef]

60. Thompson, R.N. Some High-Pressure Pyroxenes. Mineral. Mag. 1974, 39, 768-787. [CrossRef]

61. Burkhard, D.J. Kinetics of crystallization: Example of micro-crystallization in basalt lava. Contrib. Mineral. Petrol. 2002, 142, 724-737. [CrossRef]

62. Burkhard, D.J.M. Nucleation and growth rates of pyroxene, plagioclase, and Fe-Ti oxides in basalt under atmospheric conditions. Eur. J. Mineral. 2005, 17, 675-686. [CrossRef] 
63. Oze, C.; Winter, J.D. The occurrence, vesiculation, and solidification of dense blue glassy pahoehoe. J. Volcanol. Geotherm. Res. 2005, 142, 285-301. [CrossRef]

64. Baker, D.R. The fidelity of melt inclusions as records of melt composition. Contrib. Mineral. Petrol. 2008, 156, 377-395. [CrossRef]

65. Dowty, E. Crystal growth and nucleation theory and the numerical simulation of igneous crystallization. In The Physics of Magmatic Processes; Hargraves, R.B., Ed.; Princeton University Press: Princeton, NJ, USA, 1980; pp. 419-485.

66. Lofgren, G.E. Experimental studies on the dynamic crystallization of silicate melts. Phys. Magmat. Process. 1980, 487, 551 .

67. Kirkpatrick, R.J. Kinetics of crystallization of igneous rocks. Rev. Mineral. 1981, 8, 321-395.

68. Mollo, S.; Misiti, V.; Scarlato, P.; Soligo, M. The role of cooling rate in the origin of high temperature phases at the chilled margin of magmatic intrusions. Chem. Geol. 2012, 322, 28-46. [CrossRef]

69. Zhang, Y. Geochemical Kinetics; Princeton University Press: Princeton, NJ, USA, 2008.

70. Cashman, K.V. Textural constraints on the kinetics of crystallization of igneous rocks. Rev. Mineral. Geochem. 1991, 24, 314.

71. Mollard, E.; Martel, C.; Bourdier, J.L. Decompression-induced crystallization in hydrated silica-rich melts: Empirical models of experimental plagioclase nucleation and growth kinetics. J. Petrol. 2012, 53, 1743-1766. [CrossRef]

72. Arzilli, F.; Carroll, M.R. Crystallization kinetics of alkali feldspars in cooling and decompression-induced crystallization experiments in trachytic melt. Contrib. Mineral. Petrol. 2013, 166, 1011-1027. [CrossRef]

73. Ni, H.; Keppler, H.; Walte, N.; Schiavi, F.; Chen, Y.; Masotta, M.; Li, Z. In situ observation of crystal growth in a basalt melt and the development of crystal size distribution in igneous rocks. Contrib. Mineral. Petrol. 2014, 167, 1-13. [CrossRef]

74. Allwardt, J.R.; Stebbins, J.F.; Schmidt, B.C.; Frost, D.J. The effect of composition, compression, and decompression on the structure of high-pressure aluminosilicate glasses. An investigation utilizing $17 \mathrm{O}$ and 27Al NMR. In Advances in High-Pressure Techniques for Geophysical Applications; Elsevier: Amsterdam, The Netherlands, 2005; ISBN 9780444519795.

75. Gibb, F.G.F. Supercooling and the crystallization of plagioclase from a basaltic magma. Mineral. Mag. 1974, 39, 641-653. [CrossRef]

76. Sato, K.; Kashima, K.; Sunagawa, I. Measurements of nucleation rates and real growth rates of plagioclase in a solution of basaltic composition. J. Japan. Assoc. Min. Petr. Econ. Geol. 1981, 76, 294-307. [CrossRef]

77. Fokin, V.M.; Zanotto, E.D.; Yuritsyn, N.S.; Schmelzer, J.W.P. Homogeneous crystal nucleation in silicate glasses: A 40 years perspective. J. Non. Cryst. Solids 2006, 352, 2681-2714. [CrossRef]

78. Armienti, P.; Perinelli, C.; Putirka, K.D. A new model to estimate deep-level magma ascent rates, with applications to Mt. Etna (Sicily, Italy). J. Petrol. 2013, 54, 795-813. [CrossRef]

79. Granati, S.F. The Architecture of the Magmatic Feeding System of the Campi Flegrei Volcanic District: Constraints from Experimental Petrology; Sapienza University of Rome: Rome, Italy, 2016.

80. Mastrolorenzo, G.; Palladino, D.M.; Pappalardo, L.; Rossano, S. Probabilistic-numerical assessment of pyroclastic current hazard at Campi Flegrei and Naples city: Multi-VEI scenarios as a tool for "full-scale" risk management. PLoS ONE 2017, 12, 1-28. [CrossRef] [PubMed]

81. Cecchetti, A.; Marianelli, P.; Sbrana, A. Prime evidenze della esistenza di un sistema di cristallizzazione profondo ai Campi Flegrei. Atti Soc. tosc. Sci. nat. Mem. Sci. nat., Mem. 2001, 2001, 1-7.

82. Fanara, S.; Botcharnikov, R.E.; Palladino, D.M.; Adams, F.; Buddensieck, J.; Mulch, A.; Behrens, H. Volatiles in magmas related to the Campanian Ignimbrite eruption: Experiments vs. natural findings. Am. Mineral. 2015, 100, 2284-2297. [CrossRef]

83. Zollo, A.; Maercklin, N.; Vassallo, M.; Dello Iacono, D.; Virieux, J.; Gasparini, P. Seismic reflections reveal a massive melt layer feeding Campi Flegrei caldera. Geophys. Res. Lett. 2008, 35, 1-5. [CrossRef]

84. Fedi, M.; Cella, F.; D’Antonio, M.; Florio, G.; Paoletti, V.; Morra, V. Gravity modeling finds a large magma body in the deep crust below the Gulf of Naples, Italy. Sci. Rep. 2018, 8, 1-19. [CrossRef] [PubMed]

85. Pappalardo, L.; Mastrolorenzo, G. Rapid differentiation in a sill-like magma reservoir: A case study from the campi flegrei caldera. Sci. Rep. 2012, 2, 712. [CrossRef]

86. Auger, E.; Gasparini, P.; Virieux, J.; Zollo, A. Seismic evidence of an extended magmatic sill under Mt. Vesuvius. Science 2001, 294, 1510-1512. [CrossRef] 
87. Rapolla, A.; Fedi, M.; Fiume, M.G. Crustal Structure of the Ischia-Phlegrean Geothermal Fields, Near Naples, Italy, From Gravity and Aeromagnetic Datat. Geophys. J. Int. 1989, 97, 409-419. [CrossRef]

88. Esposito, R.; Bodnar, R.J.; Danyushevsky, L.V.; De, B.; Fedele, L.; Hunter, J.; Lima, A.; Shimizu, N. Volatile evolution of magma associated with the solchiaro eruption in the Phlegrean Volcanic District (Italy). J. Petrol. 2011, 52, 2431-2460. [CrossRef]

89. Piochi, M.; Mastrolorenzo, G.; Pappalardo, L. Magma ascent and eruptive processes from textural and compositional features of Monte Nuovo pyroclastic products, Campi Flegrei, Italy. Bull. Volcanol. 2005, 67, 663-678. [CrossRef]

90. Calzolaio, M.; Arzilli, F.; Carroll, M.R. Growth rate of alkali feldspars in decompression-induced crystallization experiments in a trachytic melt of the Phlegraean Fields (Napoli, Italy). Eur. J. Mineral. 2010, 22, 485-493. [CrossRef]

91. Arzilli, F.; Piochi, M.; Mormone, A.; Agostini, C.; Carroll, M.R. Constraining pre-eruptive magma conditions and unrest timescales during the Monte Nuovo eruption (1538 AD.; Campi Flegrei, Southern Italy): Integrating textural and CSD results from experimental and natural trachy-phonolites. Bull. Volcanol. 2016, 78, 72. [CrossRef]

92. Guidoboni, E.; Ciuccarelli, C. The Campi Flegrei caldera: Historical revision and new data on seismic crises, bradyseisms, the Monte Nuovo eruption and ensuing earthquakes (twelfth century 1582 ad). Bull. Volcanol. 2011, 73, 655-677. [CrossRef]

(C) 2020 by the author. Licensee MDPI, Basel, Switzerland. This article is an open access article distributed under the terms and conditions of the Creative Commons Attribution (CC BY) license (http://creativecommons.org/licenses/by/4.0/). 